NBER WORKING PAPER SERIES

\title{
WHY DO SOME FIRMS GIVE \\ STOCK OPTIONS TO ALL EMPLOYEES?: \\ AN EMPIRICAL EXAMINATION OF ALTERNATIVE THEORIES
}

\author{
Paul Oyer \\ Scott Schaefer \\ Working Paper 10222 \\ http://www.nber.org/papers/w10222 \\ NATIONAL BUREAU OF ECONOMIC RESEARCH \\ 1050 Massachusetts Avenue \\ Cambridge, MA 02138 \\ January 2004
}

We thank Corey Rosen and Ryan Weeden for providing the NCEO data, John Bishow, Anthony Barkume, and John Ruser for their assistance with the BLS data, Paul Pfleiderer and Robert McDonald for their assistance with option valuation, and Anthony Barkume, Brian Hall, Edward Lazear, Jonathan Levin, Kevin J. Murphy, Jan Zabojnik, Jeffrey Zweibel, an anonymous referee, and participants in numerous seminars for comments. The views expressed herein are those of the authors and not necessarily those of the National Bureau of Economic Research.

(C)2003 by Paul Oyer and Scott Schaefer. All rights reserved. Short sections of text, not to exceed two paragraphs, may be quoted without explicit permission provided that full credit, including (C) notice, is given to the source. 
Why Do Some Firms Give Stock Options to All Employees?:

An Empirical Examination of Alternative Theories

Paul Oyer and Scott Schaefer

NBER Working Paper No. 10222

January 2004

JEL No. J31, J33, L23, M40, M50, G32

\begin{abstract}
Many firms issue stock options to all employees. We consider three potential economic justifications for this practice: providing incentives to employees, inducing employees to sort, and helping firms retain employees. We gather data on firms' stock option grants to middle managers from three distinct sources, and use two methods to assess which theories appear to explain observed granting behavior. First, we directly calibrate models of incentives, sorting and retention, and ask whether observed magnitudes of option grants are consistent with each potential explanation. Second, we conduct a cross-sectional regression analysis of firms' option-granting choices. We reject an incentives-based explanation for broad-based stock option plans, and conclude that sorting and retention explanations appear consistent with the data.
\end{abstract}

\author{
Paul Oyer \\ Graduate School of Business \\ Stanford University \\ 518 Memorial Way \\ Stanford, CA 94305-5015 \\ and NBER \\ pauloyer@stanford.edu \\ Scott Schaefer \\ Kellogg School of Management \\ Northwestern University \\ 2001 Sheridan Road \\ Evanston, IL 60208-2013 \\ s-schaefer@northwestern.edu
}




\section{Introduction}

The use of stock option grants in compensation plans for middle- and lower-level employees has attracted ample attention in recent years. The increase in the prevalence of this practice presents a challenge to economists interested in firms' relations with their employees. ${ }^{1}$ Because the eventual value of a stock option is tied to the value of a single firm, this form of compensation subjects employees to a considerable amount of risk. In order for broad option grants to be optimal, there must therefore be offsetting benefits. In this paper, we propose and empirically examine a number of potential sources of benefits stemming from stock-option-based compensation.

We focus our analysis on three possible benefits to firms from stock-option usage. First, option grants may provide incentives to employees. Linking an employee's wealth to the value of the firm may overcome agency problems and motivate the employee to take actions that are in the firm's interest. Second, option grants may induce sorting. As with any form of non-cash compensation, potential employees may have heterogeneous assessments of the value of a firm's option grant. We consider the case where employees differ in their beliefs regarding the firm's prospects, providing an opportunity for firms to reduce compensation costs by using options to attract optimistic employees. Third, options may help firms retain employees. Any form of deferred compensation will make it costly for employees to leave. However, options may be especially useful for this purpose when stock prices and labor market conditions are positively correlated because they can index employees' deferred compensation to their outside opportunities.

We gather data from three distinct sources and seek to determine which explanation is most consistent with the option grants we observe. Our data sources offer offsetting strengths and weaknesses. Our first source, a survey conducted in 2000 by the National Center for Employee Ownership (NCEO) provides detailed information regarding salary and option packages offered to middle-level executives. However, because the NCEO surveyed only those firms it believed to have broad-based stock option plans, this sample is not useful for exploring across-firm variation in option-granting behavior.

Second, we randomly choose 1,000 publicly traded firms that filed both annual reports and proxy statements with the Securities and Exchange Commission (SEC) in calendar 1999. From these disclosures, we gather information on the number of options granted to employees in the

\footnotetext{
${ }^{1}$ Mehran and Tracy (2001) document the increase in employee stock option grants at large, publicly traded companies during the 1990's.
} 
preceding fiscal year. While this data source is representative and allows us to use detailed firmlevel information, the financial disclosures do not offer detailed information regarding grants made to middle-level employees.

Our third data source is the Bureau of Labor Statistics' (BLS) Pilot Survey of option grants made in 1999. This survey offers fairly detailed information regarding option grants, and is also selected to be representative of the U.S. economy as a whole. The main limitation of this data source is confidentiality — to insure high response rates, the BLS restricts researchers from learning the identities of the individual firms that responded. Thus, we are unable to link option-granting behavior to firm characteristics. Because of these limitations, we use the BLS data only to describe the broad patterns of stock option usage in the U.S.

We apply two distinct empirical methods to distinguish between the theories proposed above. First, we devise economic models of each theory, and calibrate these models using our NCEO data. To do this, we assume the option packages observed in our NCEO data are the product of firms' optimization over possible grant sizes. Given this, we can ask what the underlying parameters of each model must be in order to give rise to the observed option grants. We ask, for example, what an employee's production function must look like if observed option packages are optimal incentive instruments. How optimistic must employees be regarding the firm's prospects if option grants are driven by sorting? How large must short-run wage variation be if option grants are designed for retention? Second, we use our SEC sample to estimate a series of regressions that relate firms' decisions to adopt a broad-based stock option plan to firm and industry characteristics.

Our calibration of the agency model indicates that the risk premiums associated with many firms' option grants are several orders of magnitude larger than the cost to employees of the resulting increases in effort. This finding confirms the intuition that observed option grants are too small to provide strong incentives for middle-level managers. We conclude that middle-manager options are sensible for incentive purposes only under a very limited set of circumstances - namely, if employees can take actions that have very large value implications for the firm, the costs to the employee of taking these actions is very small, and it is extremely difficult for firms to observe whether employees are taking these actions.

Our results are far more consistent with the assertions that sorting and retention concerns drive broad-based stock option granting decisions. Our calibrations, for example, indicate that a somewhat risk-averse employee who expects his firm's stock to increase by about $25 \%$ annually would prefer observed option-plus-salary packages to a cash-only compensation plan that costs 
the employer the same amount. We also find that, if spot salaries for middle managers fluctuate by five to twenty thousand dollars within a few years, firms may find it more cost effective to issue stock options to middle managers than to try to adjust wages as market wages fluctuate. Finally, we interpret our cross-sectional results as further evidence consistent with options creating attraction and retention benefits. Specifically, we show that broad-based stock option plans are more common at smaller firms, firms with more volatile stock returns (and especially firms in more volatile industries), and firms with negative cash flow.

Two recent papers, Core and Guay (2001) and Kedia and Mozumdar (2002), study factors that affect option grants to non-executives. These papers use a cross-sectional approach that is methodologically similar to our logit analysis. Both papers, however, define "non-executives" as any employee other than the five highest-paid executive officers. At the cost of imposing some assumptions on the distribution of grants within firms, we attempt to improve on this definition so as to better capture grants to employees who are not senior managers. This difference in approach, as well as the insights we gain from our calibrations, lead to different conclusions. For example, Core and Guay (2001) and Kedia and Mozumdar (2002) conclude that firms' option-granting decisions are driven, at least in part, by concern for the provision of incentives.

Other authors, including Sesil, Kroumova, Blasi and Kruse (2002) and Ittner, Lambert and Larcker (2003), have studied performance effects of stock option plans. This work generally treats the adoption of stock option plans as an exogenous event, or at least takes adoption as given. Sesil et al. (2002) study differences in financial outcomes for firms with and without stock options. Ittner et al. (2003) study determinants of grants in a sample of firms that have stock option plans and measure the success of these plans against the firms' stated objectives. Our work complements this by identifying sources of performance improvements. ${ }^{2}$

Another body of work studies employee profit sharing (see, for example, Kruse (1993) and Weitzman and Kruse (1990).) Like stock options, profit sharing links compensation to firm performance. This literature has generally found small to negligible incentive and retention effects of profit sharing. Some of our analysis is similar to the profit sharing literature in that we establish characteristics of firms that issue stock options broadly.

\footnotetext{
${ }^{2}$ While we take as given that firms choose options as the form of equity to grant to employees, a few other papers have studied the choice between stock grants and stock option grants. Barron and Waddell (2003b) and Oyer and Schaefer (2003) study this decision for grants to executives and non-executives, respectively.
} 


\section{Incidence of Broad-Based Stock Option Plans}

We first examine the incidence of broad-based stock option plans, using two distinct sources of data. First, we obtain a representative random sample of U.S. for-profit establishments from the Bureau of Labor Statistics. Second, we select a random sample of 1,000 publicly traded U.S. firms, and collect information about option-granting behavior from their 1999 financial disclosures.

In 2000, the Bureau of Labor Statistics (BLS), an agency within the U.S. Department of Labor, conducted a survey of employee stock option grants during 1999. A total of 1,437 for-profit establishments, employing 680,000 people, provided complete answers to the survey. The data generated by the BLS survey have several desirable properties for providing descriptive background on the incidence of option grants. First, the BLS gets a very high response rate (over $75 \%$ ) because respondents know the confidentiality of their responses will be strictly guarded. ${ }^{3}$ Second, the BLS provides establishment-level weights that account for the distribution of establishment types in the United States, and for non-response. We use these weights so that all of our analysis, subject to standard sampling error issues, is representative of the U.S. economy in 1999. ${ }^{4}$

We generate two indicator variables intended to capture the breadth of establishment-level stock option grants. First, we set "Any Options" equal to one for any establishment that granted any stock options to any "non-owners" in $1999 .{ }^{5}$ Just $2.7 \%$ of U.S. establishments granted stock options to non-owners in 1999. A second indicator variable is intended to mimic the NCEO measure of broad-based stock option grants that we introduce below. The NCEO survey defines a program as broad if at least half the employees at a firm are eligible for stock option grants. We cannot compute a directly comparable measure using the BLS data, because the survey asks only about actual grants made within calendar 1999. Even in firms where all employees are eligible for grants, it may be the case that only a small fraction actually receive them within a given year. We therefore approximate the NCEO measure with the indicator variable "Broad Plan," which we set equal to one at any establishment that granted options to at least $20 \%$ of employees in 1999 . Only

\footnotetext{
${ }^{3}$ The BLS data is available only to researchers who are granted Intergovernmental Personnel Act assignments. All our work with this data was done on-site at the BLS in Washington, DC.

${ }^{4}$ While the BLS data are useful for descriptive purposes, their usefulness for other analysis is limited by the fact that sampling was done as the establishment (rather than firm) level and that firm anonymity prevents us from matching the option grant information to other financial information.

${ }^{5}$ There is some ambiguity in the term "owner." Technically, anyone holding a share of stock is an owner. It appears, however, that respondents interpreted "owner" as owner/operators, rather than as anyone holding shares.
} 
Table 1: BLS Sample Summary Statistics

\begin{tabular}{|c|c|c|c|c|}
\hline & \multicolumn{2}{|c|}{ Public and Private Firms } & \multicolumn{2}{|r|}{ Public Firms } \\
\hline & $\begin{array}{l}\text { All } \\
(1)\end{array}$ & $\begin{array}{c}\text { Firms with any grant } \\
(2)\end{array}$ & $\begin{array}{l}\text { All } \\
(3)\end{array}$ & $\begin{array}{c}\text { Firms with any grant } \\
\text { (4) }\end{array}$ \\
\hline B-S value of grants per & $\$ 50$ & $\$ 3,331$ & $\$ 414$ & $\$ 3,508$ \\
\hline employee & $(1,975)$ & $(15,826)$ & $(5,882)$ & $(16,833)$ \\
\hline Average Salary per employee & $\$ 31,107$ & $\$ 36,081$ & $\$ 35,438$ & $\$ 38,444$ \\
\hline & $(54,843)$ & $(63,330)$ & $(55,629)$ & $(67,028)$ \\
\hline$\%$ of employees with Salary $<\$ 35 \mathrm{~K}$ & $68.0 \%$ & $65.8 \%$ & $64.6 \%$ & $66.0 \%$ \\
\hline$\%$ of employees with Salary $>\$ 75 \mathrm{~K}$ & $6.0 \%$ & $6.7 \%$ & $6.7 \%$ & $7.0 \%$ \\
\hline Publicly Traded & $11.2 \%$ & $91.0 \%$ & $100 \%$ & $100 \%$ \\
\hline New Economy & $1.9 \%$ & $31.3 \%$ & $7.7 \%$ & $34 . \%$ \\
\hline "Broad Plan" & $1.4 \%$ & $52.0 \%$ & $11.8 \%$ & $53.5 \%$ \\
\hline Sample Size & 1437 & 150 & 373 & 137 \\
\hline Weighted Share of Sample & $100 \%$ & $2.7 \%$ & $11.2 \%$ & $2.5 \%$ \\
\hline
\end{tabular}

Establishment data are from the Bureau of Labor Statistics' 1999 Pilot Survey of Stock Option Grants. Non-profit firms and firms that did not provide complete information are not included. BLS sample weights have been applied to all numbers. "Broad Plan" indicates at least $20 \%$ of employees at the establishment were granted stock options in 1999. "New Economy" indicates primary SIC code is 3570-3579, 3661, 3674, 5045, 5961, or 7370-7379. Standard deviations in parentheses.

$1.4 \%$ of establishments in the U.S. economy meet this broad plan criteria, though almost $12 \%$ of establishments that are part of public companies qualify as having broad plans.

Table 1 shows summary statistics for the BLS data. We provide averages for all public and private establishments, all establishments with option grants, all public establishments, and all public establishments with option grants. ${ }^{6}$ From Column (1) we note that the value of options granted at a typical firm is not very high. The average establishment issues $\$ 50$ in Black-Scholes value per employee, though the value is $\$ 414$ at public companies and over $\$ 3,000$ among firms that issued any options. ${ }^{7}$ Establishments that make option grants have somewhat higher salaries on average, though they do not have a noticeably different fraction of high salary (over $\$ 75 \mathrm{~K}$ ) or

${ }^{6}$ While columns (2) and (4) include $10 \%$ and $37 \%$ of their relative samples, respectively, these proportions fall to $2.7 \%$ and $22.1 \%$ when BLS sampling weights are applied.

${ }^{7}$ In computing these Black-Scholes values, we assume all options expire in ten years. Also, because we do not observe the identity of the individual firm, we cannot use historical stock volatilities or implied volatilities from actual option markets to value these options. Instead, we use 2-digit SIC-level averages of stock volatilities. 
low salary (under $\$ 35 \mathrm{~K}$ ) workers than establishments in the sample as a whole. Not surprisingly, so-called "new economy" firms are over-represented among firms that grant options. ${ }^{8}$

The total Black-Scholes value of options granted equals approximately $3.55 \%$ of wages for all firms and $25 \%$ of wages at firms that issue some options. Of the total options granted, executives received $31.2 \%$ of the Black-Scholes value though they comprise only $2.4 \%$ of sample employment and $1 \%$ of employment at option-granting public and private establishments. Non-executives with annual salaries over $\$ 75,000$, who comprise $3.7 \%$ of sample employment and $5.7 \%$ of employment at public and private establishments that grant options, received $61.1 \%$ of the value of options granted. Employees earning under $\$ 35,000$ annually comprise $67.1 \%$ of sample employment and received just $1.6 \%$ of the value of all options granted.

The BLS statistics make it clear that stock options are an important component of compensation for non-executives at a large group of firms. While most firms do not distribute options widely, nonexecutive options comprise a significant majority of total grants. At those firms that grant options, options compensation is an important part of total labor costs. Therefore, understanding why these firms adopt this practice is an important question in understanding compensation practices.

Our second source of data is the SEC's EDGAR internet-based database of financial disclosures. From the approximately 7,000 firms that filed both a proxy statement (DEF 14A) and an annual report (10-K) with EDGAR during calendar 1999, we randomly select a sample of $1,000 .{ }^{9}$ We gather data from these disclosures regarding the number of employee stock options issued. We match this to data on accounting and stock returns from Compustat and CRSP.

The major drawback of the SEC data is its high level of aggregation; firms report how many options were granted in total, but there is no detailed information regarding the options holdings of employees other than top executives. Our aim is to construct measures of whether the firm has a stock option plan for most employees and, if so, how many options (and of what value) a typical employee holds. To construct these measures, we make use of two additional sources of information: (1) how option holdings are distributed among the firm's five most highly paid executives, and (2)

\footnotetext{
${ }^{8}$ Largely following Ittner et al. (2003), we define firms as being part of the new economy if they manufacture computers, semiconductors, or telephone equipment, if they wholesale computer-related products, or if they create software. We augment Ittner et al.'s (2003) list with codes 3575, 7375, and 7379 because the SEC and NCEO firms in these industries are internet-related.

${ }^{9}$ For most companies in our sample, the financial statements we use refer to the fiscal year coinciding with calendar 1998. We refer to our analysis as relating to 1998, though the period covered includes part of 1997 or 1999 for some firms.
} 
data from the NCEO survey on option grants. ${ }^{10}$

We begin by constructing an estimate of the number of options granted to non-executives. Core and Guay (2001) and Kedia and Mozumdar (2002) define non-executive stock option grants as all grants to employees that are not among the five highest paid workers at the firm. While this measure is easy to construct consistently across firms, it undoubtedly overestimates the number of options granted to non-executives because, at many firms, the sixth, seventh, etc. highest paid executives also receive very large option grants. ${ }^{11}$ Because our aim is to study option grants to middle-level employees, it does not seem appropriate to include grants to these top executives in our measure.

Improving on a simple top five executive cutoff comes at the cost of imposing some assumptions, however. CEOs often receive a significantly greater option grant than anyone else at the firm, so we start by focusing on the executives with the second through fifth largest grants. We assume that the highest $10 \%$ of employees at the firm receive an average grant one tenth as large as the average executive in the second through fifth compensation rank. We subtract these shares and shares granted to the top five executives from the total grants to employees, and assume the difference is the total shares granted to non-executives. If the difference is negative, then we assume there were no grants to non-executives. We define an indicator variable (SEC Plan) that equals one if the number of shares granted to non-executives represents at least $0.5 \%$ of the shares outstanding in $1998 .^{12}$

Table 2 displays summary statistics for the firms in the SEC dataset. All firms are included in the first column, while columns (2) and (3) partition the firms into groups with SEC Plan $=1$

\footnotetext{
${ }^{10}$ We know with certainty whether or not the firms in the NCEO sample have a broad-based option plan. We compare the survey data from the NCEO with the information in NCEO firms' SEC disclosures. Loosely, our approach attempts to maximize the number of NCEO sample firms for which we accurately predict option plan status.

${ }^{11}$ To show the importance of option grants to executives who miss the top five cutoff, we used the Execucomp dataset to look at option grants at companies that report compensation details for more than five executives in a given proxy statement. There are 3,236 firm/year observations with more than five listed executives between 1996 and 2002. $57.4 \%$ of this sample made option grants to the fifth highest paid executive, while $33.4 \%$ made grants to the sixth highest paid. Among those who received grants, Execucomp's valuation of the Black-Scholes value of the grants for the average (median) executive is $\$ 802 \mathrm{~K}(\$ 266 \mathrm{~K})$ for fifth highest executives and $\$ 782 \mathrm{~K}(\$ 253 \mathrm{~K})$ for sixth highest paid. Average and median grant values are similar for seventh and eigth highest paid executives in the firm/years where details are provided.

${ }^{12}$ In Section 5 below, we construct two alternative indicators for the presence of a broad-based stock option plan using our SEC data. Reproducing Table 2 with these indicators yields similar patterns.
} 
Table 2: SEC Sample Summary Statistics

\begin{tabular}{lccc}
\hline \hline & All Firms & Option Plan & No Option Plan \\
& $(1)$ & $(2)$ & $(3)$ \\
\hline Black-Scholes value of non-exec & $\$ 17,891$ & $\$ 36,982$ & $\$ 288$ \\
grants per employee & $(52,351)$ & $(70,829)$ & $(1,285)$ \\
Grants to non-execs/Total Shares & $2.2 \%$ & $4.4 \%$ & $0.1 \%$ \\
& $(4.2 \%)$ & $(5.2 \%)$ & $(0.1 \%)$ \\
Employees & 5,684 & 970 & 10,032 \\
& $(18,742)$ & $(2,519)$ & $(25,112)$ \\
Employee Growth & $26.0 \%$ & $38.2 \%$ & $14.3 \%$ \\
& $(168 \%)$ & $(237 \%)$ & $(34 \%)$ \\
Market Value & $\$ 1,660$ & $\$ 450.6$ & $\$ 2,815$ \\
12/98 - (\$MM) & $(10,451)$ & $(1,605)$ & $(14,446)$ \\
Fraction with Positive Cash Flow & $78.0 \%$ & $61.9 \%$ & $92.8 \%$ \\
1997 Stock Return & $24.0 \%$ & $20.0 \%$ & $27.4 \%$ \\
& $(61.8 \%)$ & $(67.3 \%)$ & $(56.6 \%)$ \\
1998 Stock Return & $5.9 \%$ & $8.1 \%$ & $4.2 \%$ \\
& $(82.5 \%)$ & $(108.1 \%)$ & $(49.8 \%)$ \\
1999 Stock Return & $33.1 \%$ & $62.0 \%$ & $6.3 \%$ \\
Monthly Volatility & $(161.8 \%)$ & $(213.5 \%)$ & $(82.2 \%)$ \\
New Economy & $17.5 \%$ & $20.9 \%$ & $14.2 \%$ \\
Sample Size & $(9.6 \%)$ & $(10.2 \%)$ & $(7.7 \%)$ \\
\hline
\end{tabular}

Data are from a random sample of 1,000 firms that filed 10-Ks and proxy statements with the SEC in calendar 1999. The final sample of 798 firms includes those for whom we were able to gather stock return and other financial information. Column (2) includes firms that, during the covered fiscal year, we estimate issued options on at least $0.5 \%$ of its outstanding shares to employees who were not in the top $10 \%$ of its management ranks. Column (3) includes firms that did not meet this criterion. This rate of grant is capped at $30 \%$. "New economy" indicates primary SIC code is $3570-3579,3661,3674,5045,5961$, or 7370-7379. Standard deviations in parentheses. 
and SEC Plan $=0$, respectively. We find $48.9 \%$ of the firms in our sample had broad-based stock option plans in 1998, though, because these plans are more common at small firms, only $8.3 \%$ of employees in the sample worked at firms with SEC Plan $=1$. Employees at SEC Plan $=1$ firms received average grants worth in excess of $\$ 36,000$ (though the average option value at the median firm with SEC Plan $=1$ is only $\$ 6,551$.) Table 2 makes clear that SEC Plan $=1$ firms are strikingly smaller, faster growing, and their stock returns are more volatile. ${ }^{13}$ New economy firms make up a substantial portion of the firms with broad plans. Also, note that only three-fifths of the firms with broad plans generated positive cash flow in 1998 (defined as earnings before extraordinary items plus depreciation), while more than $90 \%$ of the SEC Plan $=0$ firms generated cash.

\section{Models and Empirical Implications}

In this section, we outline several models that may help explain why firms elect to issue options to a broad group of employees. We summarize the implications of each model to motivate the empirical analysis that follows.

\subsection{Incentives}

We first describe an incentives-based justification for use of equity in compensation. Suppose the value of the firm, $V$, depends on an employee's effort, $e$, as follows: ${ }^{14}$

$$
V=v e+\epsilon_{v}
$$

where $\epsilon_{v}$ is a normal random variable with mean zero and variance $\sigma_{v}^{2}$. Let the employee be risk averse with coefficient of absolute risk aversion $\varphi \cdot{ }^{15}$ Suppose further that the employee has

\footnotetext{
${ }^{13}$ Our adjustment to Core and Guay's (2001) method of measuring grants to non-executives appears to be important. Had we defined our SEC Plan variable similarly but without adjusting for possible grants to non-top-five executives, then we would have concluded that broad option plans are more common at larger firms. This suggests that Core and Guay's (2001) finding that option-based incentives for non-executives are stronger at larger firms may be an artifact of their data collection methodology. It may simply reflect that larger firms grant more options to non-top-five executives.

${ }^{14}$ Here, we follow the linear contracting agency model studied by Holmstrom and Milgrom (1987, 1991). While this model's assumptions of linear contracts and normal disturbances are unlikely to be met in the option-based-pay context we study here, it is convenient for its analytic simplicity. In our calibration below, we develop an agency model that is more closely tailored to the stock-option context.

${ }^{15}$ We denote by $\varphi$ a coefficient of absolute risk aversion, and by $\rho$ a coefficient of relative risk aversion.
} 
quadratic effort costs, with second derivative $c$.

The optimal contract in this case is linear in firm value, and maximizes the total certainty equivalent subject to the employee's incentive constraint. If $b$ is the share of the firm that is owned by the employee, then the optimal contract features

$$
b=\frac{v^{2}}{v^{2}+\varphi c \sigma_{v}^{2}} .
$$

This analysis yields the standard comparative statics of agency theory. The employee's share is higher when the variance of firm value, conditional on the employee's effort, is smaller; the marginal return to effort, $v$, is higher; the second derivative of the employee's cost of effort function, $c$, is smaller; and the employee is less risk averse.

While the second through fourth comparative statics are difficult to test without detailed information about the production function or employees' preferences, one may think to test this theory using the first. In fact, there is a large literature testing this comparative static using the payfor-performance contracts of top executives. Murphy (2000) surveys many of the relevant papers. Aggarwal and Samwick (1999) and Jin (2002), for example, confirm the negative risk/incentive relationship for Chief Executive Officers, while Barron and Waddell (2003a) confirm the relationship for the top five executives at a given firm. Many other papers have analyzed this relationship using the compensation data provided for five executives in proxy statements or for a slightly larger group of top managers surveyed by consulting firms (see, for example, Bushman, Indjejikian and Smith (1995) and Keating (1997).) We test this prediction of the incentive model in our cross-firm analysis of option plans in Section 5 below.

Previous cross-sectional tests of the risk/incentive relationship, as well as our test below, are complicated by several factors, however. First is the potential correlation between the marginal return to effort and the variance of the firm's market value. Given that the econometrician cannot observe the marginal return to effort, any cross-sectional analysis of the link between incentives and firm risk suffers a potential omitted variable bias. If effort is more valuable in high-risk environments (as Prendergast (2002) suggests it may be in some cases), then employees' ownership may appear to be increasing in firm risk due to this correlation.

Second, equity-based instruments are not the only way in which firms can provide incentives to employees. Firms use many measures that reflect actions of individual employees. Agency theory suggests that if an individual employee's performance is measured less precisely, then the firm will substitute toward other measures, such as overall firm performance. Note the econometrician typically cannot observe the efficacy of individual performance measures, so again cross-sectional 
tests suffer from an omitted variable bias. Indeed, Core and Guay (2001) take this observation to something of an extreme, arguing that "monitoring costs" (which one can interpret as the absence of good measures of individual employee performance) are increasing in firm size, thus predicting that larger firms should make greater use of option-based compensation. This prediction is the opposite of what one might expect given that the variance of market value is typically higher for larger firms.

Because of the difficulty in measuring theoretically important constructs such as the marginal return to effort and the variance of measures of individual performance, it is not clear what pattern in cross-sectional data could reject an incentives-based explanation for stock option use. Given these problems with cross-sectional tests, we therefore supplement standard methods with a different approach. In Section 4.1 below, we directly calibrate an agency model, and ask whether the observed option packages offered to middle managers appear to be an efficient means for providing incentives.

\subsection{Sorting}

Next, we consider the possibility that firms may offer option-based compensation to induce workers to sort into the most efficient employment matches. Traditional models of sorting (see, for example, Lazear (2001) ) suggest firms may want to tie some of its employees' pay to firm performance as a means of attracting able employees to work at the firm. However, non-executives generally have sufficiently little effect on firm value that even a small amount of risk aversion would make the risk costs of options dwarf the benefits of this sorting. We therefore consider a model where employees are heterogeneous in their beliefs regarding the firm's prospects. Given this assumption, the firm may benefit by using stock options to attract the optimistic employees. If employees value the firm's stock options at more than their market price, then the firm can reduce its overall compensation expenses by offering option-based pay packages.

There are three reasons why it may be advantageous to include such compensation as part of an employment relationship, as opposed to simply letting optimistic employees purchase the firm's shares in their own account. First, if optimistic employees are relatively willing to invest in firm-specific human capital, to work hard, or are otherwise more productive, the firm needs to make options a condition of employment to insure more productive workers self-select into the firm. Second, there is a tax advantage. The employment relationship allows the employee to avoid 
paying taxes on the options until he exercises them. ${ }^{16}$ This allows the options to compound taxfree (though the tax advantage is not large.) Finally, it may be that the firm can somehow reduce overall transaction costs by making these grants centrally. ${ }^{17}$

This explanation for firms' option granting behavior has several empirical implications. First, option grants will increase with employees' tax rates because the tax benefits of being paid in options will be greater. Given progressive income taxation, this suggests option grants should be larger for higher-paid workers. Second, option grants will increase in the variance of employees' beliefs about the value of options. If the variance of beliefs is greater, the firm will be able to extract a larger compensation discount from the most optimistic workers. Finally, firms will be more likely to grant options as the relative productivity of optimistic workers increases relative to other workers.

\subsection{Retention}

Because options granted to employees typically have a vesting period attached, they have the effect of increasing the costs to employees of departing the firm. Options may therefore help firms retain employees. What is unclear, though, is why firms would use stock options for this purpose - any form of compensation that is forfeited if employees leave will help with retention. Given that using options for this purpose loads risk onto employees, one may wonder why firms would not simply defer cash payments if retention is their aim.

The model in Oyer (2003) suggests an answer. If labor market conditions in a given industry are positively correlated with firms' share prices, then options serve to index deferred compensation

\footnotetext{
${ }^{16}$ Firms issue two types of stock options to employees - "incentive stock options" (ISOs) and "non-qualified stock options" (NQSOs). ISOs create significant tax complications because they have the potential advantage of recognizing more income as capital gains, but they can lead to Alternative Minimum Tax consequences. This has minimal effect on our analysis because the IRS restricts issuance of ISOs and, therefore, a significant majority of stock options issued to individuals below the top executive level are NQSOs. Our BLS data show that $77 \%$ of the people who received options grants in 1999 received only NQSOs, 15\% received only ISOs, and 8\% received both. The ISOs are skewed towards senior executives. Some non-executives do receive ISOs and, therefore, our analysis slightly understates the average (but not the median) tax advantages of stock options. See McDonald (2003) for details on employer tax considerations in issuing options. We proceed under the assumption that the options we analyze are NQSOs.

${ }^{17}$ Employees may also gather inside information that enhances the value of the options they are granted (see Huddart and Lang (2003)). However, employees can make full use of this information (and optimize given their individual risk preferences) by trading on their own accounts. Thus, the presence of such inside information cannot by itself explain why firms elect to issue options to employees.
} 
to employees' outside options. Consider a firm that is contemplating offering $\$ 100,000$ in deferred cash compensation versus $\$ 100,000$ in Black-Scholes value of stock options. If it turns out that labor markets are exceptionally tight, then the $\$ 100,000$ in deferred cash may not be sufficient to induce the employee to stay with the firm. However, if the employee holds options, then it is likely that the value of the option package will be substantially higher than $\$ 100,000$ in the event that the employee receives an attractive outside offer. The states of the world in which the firm incurs costs from replacing the employee (if he leaves) or negotiating over a new wage (if he can be convinced to stay) is smaller given the option package.

If, on the other hand, labor markets are slack, then the firm must still pay the employee the $\$ 100,000$ in deferred cash. For the option package, though, the realized value may be considerably less than the initial Black-Scholes value. Given the widely held view that it is difficult for firms to cut nominal salaries, the option package may be an effective way to link total compensation to labor market conditions without resorting to nominal wage cuts. In Oyer's (2003) model, the adoption of broad-based stock option plans increases with the firm's costs of replacing workers, the variance of common shocks to firms participating in a given labor market, employee risk tolerance, and variance in local market wages.

\subsection{Other Explanations}

We focus on the preceding three explanations in our analysis, but briefly recount some others here.

\subsubsection{Financing Constraints}

Some have suggested that cash-constrained firms offer stock options to their employees as a substitute for salary. This explanation may hold some intuitive appeal, especially given the prevalence of option-based pay in new ventures. There is a substantial literature (see Stein (2001)) examining information asymmetries in financial markets; frictions in markets may lead to a preference for internal finance.

We have two reservations regarding this hypothesis. First, the evidence on the relationship between financing constraints and option grants is, at best, mixed. Core and Guay (2001) find that option grants to "non-executives" are greater at firms that have larger cash flow shortfalls from operations. Kedia and Mozumdar (2002) look for an association between option grants and several proxies for financing constraints. They find that options grants are higher at firms with higher losses carried forward, though they find that option grants are not related to interest coverage or 
dividend payout. Ittner et al. (2003), on the other hand, find "no evidence that cash constrained new economy firms make greater use of equity-based compensation to conserve cash" using cash on hand per employee and cash flow per employee as proxies for cash constraints. Finally, Bergman and Jenter (2003) find that non-executive grants are positively related to high cash levels and not to leverage, interest burden, or distress. They argue that, "these findings contradict the notion that option compensation is used to alleviate financing constraints."

Second, we argue this hypothesis is difficult to support with economic theory unless one allows for the possibility that employees may have optimistic assessments of firm value. Corporate finance theory suggests that firms should seek the lowest-cost forms of financing; therefore, this "optionsas-finance" explanation is sensible only if asking employees to take a discount in salary is the lower-cost way to financing than, say, doing a seasoned equity offering. While there are transaction costs associated with any equity offerings, there are a number of reasons why we would expect the costs of using middle-level employees as financiers would be higher. First, the informational asymmetries afflicting financial markets would presumably affect attempts to finance through the labor market as well. While employees may have the opportunity to gather ample information regarding the firm's operations after they take the job, the decision by an employee to accept a lower salary in exchange for equity is made before much of this information is gathered. Second, even if a firm's employees are advantaged relative to outside financiers in observing management's actions, the weak control rights associated with small option grants means there is little employees can do to protect their investments. Third, specialist financial intermediaries would presumably have more expertise in assessing new ventures and greater risk tolerances than would middle-level employees.

Thus, to make sense of financing constraints as an explanation for option usage, one needs to identify conditions under which employees are the lowest-cost source of capital. Given that riskaverse employees would demand a higher return than other investors, it must be that employees who provide capital to their employers expect higher returns than other investors. This could result, for example, from a potential employee having inside information from a friend working at the company or from the employee simply having relatively high expectations for a firm or its industry. This suggests that employees are the cheapest source of capital when they are more optimistic than alternative investors regarding the firm's prospects, which is precisely the sorting idea we discussed in Section 3.2. ${ }^{18}$

\footnotetext{
${ }^{18}$ The uncertain prospects of many start-up firms are likely to make it difficult for them to reward employees
} 
While we claim that the financing constraints hypothesis is an incomplete form of the sorting model, note that financing constraints are not a necessary condition for the sorting model to hold. Firms that have plenty of cash on hand would still have an incentive to use options as a form of compensation if some potential employees value those options more highly than equity markets. In fact, Oyer and Schaefer (2003) argue that sorting may explain Microsoft's long tradition of broad equity grants even though Microsoft has plenty of cash available to fund current compensation expenses. ${ }^{19}$ If sorting is an important determinant of broad option plans, but only some of the time broad options help firms avoid raising money externally, this could explain the inconsistent empirical correlation between option grants and proxies for financing constraints.

\subsubsection{Favorable Accounting Treatment}

As Hall and Murphy (2003) emphasize, stock-option-based compensation receives a favorable accounting treatment. If a firm pays an employee an additional $\$ 100$ in wages, then this payment is counted as an expense for the firm, and the firm's reported net income in the current period is lower by $\$ 100$. If, on the other hand, a firm gives an employee a stock option grant worth $\$ 100$, then the firm may elect not to recognize this as a compensation expense. Under this accounting regime, a firm interested in boosting its share price in the short run may try to reduce compensation expense by using options rather than cash. Magnitudes of option grants, however, must be disclosed. (Such disclosures are the source of our SEC data set.) Unless equity prices fail to reflect this publicly available information, attempts to fool the market by shifting to option-based pay will fail. It is not clear how precisely stock prices incorporate option grant information. Based on several papers, including Aboody (1996), Huson, Scott and Wier (2001), and Aboody, Barth and Kasznik (2001), it is generally accepted that market valuations are affected by this information. Bell, Landsman, Miller and Yeh (2002) confirm that option grants affect valuations, but suggest that their findings "call into question whether investors assess correctly the effect of [employee stock options] on profitable software firm value." Also, Garvey and Milbourn (2002) propose a trading rule based on the

through self-enforcing implicit contracts based on subjective measures of performance (see Bull (1987)). These firms may therefore substitute toward explicit contracts based on share prices. While we believe this explanation may be of some value in explaining the use of options in small startup firms, it cannot explain why a large, established firm would grant options to all employees.

${ }^{19}$ Oyer and Schaefer (2003) also argue that the financing constraints explanation for option grants suggests that firms should issue stock, not options, to employees, because doing so results in smaller employee risk premiums. 
market's failure to perfectly incorporate option grant data.

Even if the market is not systematically fooled by firms' attempts to hide compensation expense using stock options, top managers may still issue options to lower level employees if they naively believe the market can be fooled, or if their own compensation depends more on accounting earnings than share prices. This reasoning suggests that a corporate governance problem underlies firms' decisions to issue options, as the separation of ownership and control permits managers to take actions that owners would undo if they could.

While we acknowledge that accounting may have some effect, we argue that this rationale is not solely responsible for the decision by firms to adopt broad-based option plans. We base this on the implied cost of the corporate governance problem that would generate observed nonexecutive option grants and on the fact that there is little evidence of any connection between broad option grants and lax corporate governance. Oyer and Schaefer (2003) estimate that, if the only benefit of non-executive grants is favorable accounting treatment, a typical firm with a broadbased stock option plan incurs real costs of about $\$ 3,000$ per middle manager per year in order to increase reported pre-tax income by about $\$ 9,000$. In addition, a typical firm with a broad-based plan exhibits a marginal willingness to pay $\$ 0.64$ of actual costs (in the form of risk premium to employees) in order to increase pre-tax income by one dollar. Given that compensation costs are an important component of these firms' cost structure, it is difficult to imagine these firms could stay competitive if they wasted resources at that rate.

There are several well-established facts that, taken together, suggest there is no connection between lax corporate governance and broad option grants. First, ownership of equity by Chief Executives rose dramatically during the 1990s (Murphy (2000)), which is the same time period as option grants to non-executives grew (Hall and Murphy (2003)). Second, many firms that used broad plans (such as Microsoft and Oracle) are managed by founders with very large equity stakes. Third, corporate governance is no weaker (and perhaps somewhat stronger) among the types of firms (for example, small firms and technology-based firms) that we show below to be relatively likely to issue options broadly (Gompers, Ishii and Metrick (2003)). Finally, some privately held firms elect to issue stock options to employees. Accordingly, we take as our starting point the assertion that broad-based stock option plans are in shareholders' interests, and search for underlying sources of value creation. 


\section{Calibrations}

In this section, we fit data on stock option grants to the incentive, sorting, and retention models discussed above. Here, we rely on the 2000 Survey on Current Practices in Broad-Based Stock Option Plan Design conducted by the National Center for Employee Ownership (NCEO). The NCEO is a private, non-profit organization that provides members with information about employee ownership programs. In March of 2000, they sent questionnaires to compensation administrators at approximately two thousand companies seeking detailed information about their stock option plans. The list of surveyed companies was compiled from several sources and all were thought likely to have a stock option plan that covered at least half the company's employees. The NCEO received 247 detailed responses from firms that had stock option plans covering the majority of employees. For each of these firms, we search the 2000 Ward's Business Directory for basic firm-level data, such as primary SIC code, number of employees, year founded, and annual revenue. This survey was not designed to cover a random sample of firms that might issue options, so we use the survey only to analyze characteristics of observed plans.

\subsection{Incentives}

We begin by considering an incentives-based explanation for stock option use. As noted above, agency theory suggests that the marginal return to effort and the efficacy of alternative performance measures should be key determinants of the use of equity-based compensation. The fact that these constructs are not observed by the econometrician makes assessing an agency-theoretic explanation for option use very difficult in cross-sectional data. Because firms do not frequently vary the variable that is of interest to us (namely, the existence of a broad option plan), we are limited to cross-sectional data. As such, we supplement our across-firm analysis with a different approach.

The intuition underlying our incentives calibration is the following: If observed option grants are optimal, then the marginal benefit to the firm of making additional grants must equal the marginal cost. The marginal benefit comes from additional effort leading to additional productivity, while the marginal cost comes from the fact that an employee must be compensated for bearing additional risk. We calibrate the firm's first-order condition, using observed option packages, observed variances of firms' market values, and information about individuals' typical levels of risk aversion. This allows us to calculate the value, gross of risk and effort costs, associated with observed stock option grants. We can also compute the employee's effort cost and risk premium. Given these fig- 
ures, we can ask whether observed option grants appear to be consistent with an incentives-based justification for stock option use.

Formally, we let $v_{0}$ be the value of the firm as of the date of an option grant. Suppose the employee makes an effort choice $e$ that affects the terminal value of the firm $\left(v_{1}\right) \cdot{ }^{20}$ Let the cumulative distribution function of $v_{1}$ conditional on $e$ be represented by $F\left(v_{1} ; e\right)$. We normalize effort such that one unit increases the mean of $v_{1}$ by $\$ 1$. Let $b$ be the fraction of any appreciation in the firm's value that is given to the employee as part of the option grant. If the firm grants options on $n$ shares to an employee and has $N$ shares outstanding, then $b=\frac{n}{n+N}$. The final payoff to the employee from his grant of stock options is therefore given by $\max \left[b\left(v_{1}-v_{0}\right), 0\right]$.

Suppose the employee has constant absolute risk aversion with coefficient $\varphi$. We use a Taylor series approximation of the employee's utility function to write the employee's certainty equivalent when holding random payoff $\tilde{x}$ as $\mathrm{E}(\tilde{x})-(1 / 2) \varphi \operatorname{Var}(\tilde{x})$. Let the employee's utility in his next best job be given by $\bar{u}$.

The firm's problem is to select a salary $s$ and an option grant $b$ to maximize its profits. The assumption of no wealth effects allows us to simplify the firm's problem by substituting the employee's participation constraint into the firm's objective. The firm selects $b$ to maximize the total certainty equivalent of the two parties less effort costs, subject to the employee's incentive constraint:

$$
\max _{b} \int_{0}^{\infty} v_{1} d F\left(v_{1} ; e\right)-c(e)-\frac{1}{2} \varphi b^{2} \xi(e)
$$

subject to

$$
e \in \arg \max _{e} b \int_{v_{0}}^{\infty} v_{1} d F\left(v_{1} ; e\right)-c(e)-\frac{1}{2} \varphi b^{2} \xi(e) .
$$

Here, we have defined $\xi(e)$ to be the variance of $\max \left[v_{1}-v_{0}, 0\right]$ conditional on the employee's effort level.

The employee's first-order condition for effort is given by

$$
b \int_{v_{0}}^{\infty} v_{1} f_{2}\left(v_{1} ; e\right) d v_{1}-c^{\prime}(e)-\frac{1}{2} \varphi b^{2} \xi^{\prime}(e)=0,
$$

where $f_{2}$ is the derivative of the density of the firm's terminal value with respect to the employee's effort choice. We define $\hat{e}(b)$ as the solution to this equation - it is the employee's optimal effort choice conditional on the firm's option grant.

\footnotetext{
${ }^{20}$ While we model this as though the agent works in isolation, $e$ can be interpreted as the sum of all effort that is distasteful (on the margin) to the employee and can include monitoring of co-workers. Also, the mapping of $e$ to firm value can include complementarities across workers so that the marginal contributions of individual workers can be greater than the total firm value.
} 
Assuming an interior optimum, the optimal option grant satisfies

$$
\hat{e}^{\prime}(b)\left(\int_{0}^{v_{0}} v_{1} f_{2}\left(v_{1} ; \hat{e}(b)\right) d v_{1}+(1-b) \int_{v_{0}}^{\infty} v_{1} f_{2}\left(v_{1} ; \hat{e}(b)\right) d v_{1}\right)=\varphi b \xi(\hat{e}(b)) .
$$

This equation has an intuitive interpretation. The left-hand side is the amount by which the value captured by the firm increases when $b$ increases by a small amount. It is the product of the derivative of effort with respect to $b$ and the derivative of value captured by the firm with respect to effort. The right-hand side is the amount the employee's risk premium increases when the firm increases $b$. The optimal option grant equates this marginal benefit to this marginal cost.

We rely on the first-order conditions in Equations (1) and (2) in conducting our calibration exercise. We take characteristics of the firm and its option grants from our NCEO data and make assumptions regarding the distribution of the terminal value of the firm $(f)$ and the risk aversion of the employee $(\varphi)$. Given this, the only unknowns in this pair of first-order conditions are the employee's effort level $e$, and his marginal cost of effort $c^{\prime}(e)$. Assuming effort costs are quadratic with second derivative $c$, we then have two equations with two unknowns, which we can solve numerically. Our normalization of effort means that a calculation of $e$ gives the dollar value of the employee's increased production coming about as a result of the option grant. Given $c$, we can compute the cost to the employee of exerting this effort. We can also compute the risk premium the employee applies to the option grant.

To tailor our analysis to the stock-based pay context, we make a number of assumptions. First, we let one period in our model correspond to four calendar years. The employee receives an option grant at the beginning of the first year and either exercises his options or leaves the firm (forfeiting the option value) at the end of the fourth year. This assumption is motivated by the fact that most option packages granted by firms in our NCEO data are fully vested after four years, and that research on option granting behavior by lower-level employees suggests that a large fraction of these options are exercised very shortly after vesting. ${ }^{21}$ The assumption implies that the value (to the risk-neutral firm) of the option is equivalent to the Black-Scholes value of an option that expires after four years. We use this as the cost to the firm of issuing the options to the employee.

\footnotetext{
${ }^{21}$ For example, Aboody (1996) shows that, in a sample of 478 firms with relatively large numbers of outstanding options, most firms issue options with a ten-year term and most options were exercised in the first four years after the grant date. Huddart and Lang (1996) study a sample of eight firms, and report that about half of all options were exercised in the first half of the options' term. At the public companies in our NCEO sample, survey respondents indicated that approximately $25 \%$ of options were exercised immediately upon vesting, an additional $31 \%$ were exercised within a year after vesting, and $21 \%$ were exercised between one and two years after vesting.
} 
Second, we assume that the distribution of the terminal value of the firm follows a log-normal distribution. The mean of this distribution is given by $v_{0}(1+r)^{4}+e$, where $v_{0}$ is the value of the firm at time zero, $r$ is the annual expected return on the firm's shares, and $e$ is the effort level chosen by the employee. We set $r=10 \%$ in our analysis. The standard deviation of this distribution is given by $2 \sigma v_{0}$, where $\sigma$ is the expected annual standard deviation of the firm's return.

For public companies in our NCEO sample, we estimate a historical value of $\sigma$ using stock return data from the Center for Research in Securities Prices (CRSP) from 1995 through 2000. For the 86 companies that are private or for which historical stock returns are insufficient, we compute a historical $\sigma$ using the predicted level from a regression of $\sigma$ on the firm's number of employees using the 130 companies for which we can compute historical volatilities. For our calculation of option values, we would like to apply expectation of future stock volatility, rather than the historical volatility we compute. Implied volatilities from options markets show that future and historical levels are similar in short forward-looking horizons (a year or two), but markets going out four years do not exist. We therefore assume that future volatilities will be the minimum of 0.75 and $75 \%$ as high as the computed historical volatilities.

We consider two possible values for the employee's level of risk aversion, and two possible employee cost-of-effort functions. Friend and Blume (1975) and Hall and Murphy (2002) argue that 2.5 is a rough lower bound on the average person's coefficient of relative risk aversion $(\rho)$. To allow for the possibility that option-based pay attracts a selection of risk-tolerant employees, however, we use a relative risk aversion value of one in our basic specification. We convert this to an Arrow-Pratt measure of absolute risk aversion (as required by our agency model) by dividing by the employee's wealth level, which we assume to be five times the annual salary paid by the firm to middle managers. We also consider the case where middle managers are of "average" risk tolerance (that is, $\rho=2.5$ ). In our basic specification, we assume quadratic effort costs with second derivative $c$. We also apply $c(e)=\frac{1}{4} c e^{4}$.

In Table 3, we present a summary of the results from this exercise. We select four firms, one from each employment size quartile, from our NCEO data. Note first that the value of option grants to middle managers varies considerably in the sample. The typical firm grants options with a Black-Scholes value equal to approximately one year of salary, though the "Large Firm" in column (4) grants three years of salary to new middle managers (worth a total of over a quarter of a million dollars.) Note, however, that while some of these firms make valuable grants, the middle manager typically owns a very small fraction of the firm (less than one one-thousandth of a percent 
Table 3: Calibration - Incentives

\begin{tabular}{|c|c|c|c|c|c|}
\hline & $\begin{array}{c}\text { Small Firm } \\
\text { (1) }\end{array}$ & $\begin{array}{c}\text { Med-Small Firm } \\
\text { (2) }\end{array}$ & $\begin{array}{c}\text { Med-Large Firm } \\
(3)\end{array}$ & $\begin{array}{c}\text { Large Firm } \\
\text { (4) }\end{array}$ & $\begin{array}{c}\text { Medians } \\
\text { (5) }\end{array}$ \\
\hline Employees & $<50$ & $<100$ & $\sim 300$ & $10,000+$ & 180 \\
\hline Middle Manager Salary & $\$ 38$ & $\$ 100$ & $\$ 90$ & $\$ 90$ & 90 \\
\hline Employee Share $(b)$ & $0.015 \%$ & $0.052 \%$ & $0.009 \%$ & $0.00011 \%$ & $0.0404 \%$ \\
\hline Firm Value (April 2000 - \$millions) & $<\$ 100$ & $\sim \$ 200$ & $\sim \$ 300$ & $>\$ 50,000$ & $\$ 230$ \\
\hline Stock Volatility $(\sigma)$ & $>75 \%$ & $>75 \%$ & $<75 \%$ & $>50 \%$ & $72 \%$ \\
\hline Black-Scholes Value & $\$ 52$ & $\$ 95$ & $\$ 11$ & $\$ 272$ & $\$ 92$ \\
\hline \multicolumn{6}{|l|}{ Case One: $\rho=1, c(e)=\frac{1}{2} c e^{2}$} \\
\hline Effort $(e)$ & $\$ 10.2$ & $\$ 9.3$ & $\$ 0.18$ & $\$ 63.5$ & $\$ 8.71$ \\
\hline Cost of Effort $(c(e))$ & $\$ 0.0026$ & $\$ 0.0014$ & $\$ 0.000005$ & $\$ 0.000023$ & $\$ 0.0010$ \\
\hline Risk Premium & $\$ 4.6$ & $\$ 4.3$ & $\$ 0.088$ & $\$ 22.6$ & $\$ 2.76$ \\
\hline \multicolumn{6}{|l|}{ Case Two: $\rho=2.5, c(e)=\frac{1}{2} c e^{2}$} \\
\hline Effort $(e)$ & $\$ 50.6$ & $\$ 35.9$ & $\$ 0.457$ & $\$ 1,511.5$ & $\$ 148.5$ \\
\hline Cost of Effort $(c(e))$ & $\$ 0.011$ & $\$ 0.0054$ & $\$ 0.000012$ & $\$ 0.0005$ & $\$ 0.011$ \\
\hline Risk Premium & $\$ 11.5$ & $\$ 10.9$ & $\$ 0.22$ & $\$ 56.5$ & $\$ 6.92$ \\
\hline \multicolumn{6}{|l|}{ Case Three: $\rho=1, c(e)=\frac{1}{4} c e^{4}$} \\
\hline Effort $(e)$ & $\$ 31.7$ & $\$ 29.1$ & $\$ 0.683$ & $\$ 223.5$ & $\$ 28.5$ \\
\hline Cost of Effort $(c(e))$ & $\$ 0.0040$ & $\$ 0.0023$ & $\$ 0.000010$ & $\$ 0.0004$ & $\$ 0.0019$ \\
\hline Risk Premium & $\$ 4.6$ & $\$ 4.3$ & $\$ 0.088$ & $\$ 22.6$ & $\$ 2.76$ \\
\hline
\end{tabular}

Risk-free rate is assumed to be 5\%. Options assumed to expire in ten years and fully vest in four years. All dollar values are in thousands except firm value. 
in the case of the large firm). In contrast, "senior managers" of these same firms get grants of approximately eight times as many shares and the top executives of some of the bigger firms get grants that are several orders of magnitude greater than grants to middle managers. ${ }^{22}$ Therefore, though the BLS statistics in Section 2 indicate that high paid non-executives, such as the middle managers we study, receive the majority of total option grants, we expect the incentive effects of these grants to be very different from those for top executive analyzed by, for example, Hall and Murphy (2002).

We present results from three calibrations for each of the four firms in the table. The first calibration assumes quadratic effort costs and absolute risk aversion of one divided by five times salary. The second assumes quadratic effort costs and absolute risk aversion of 2.5 divided by salary. The third assumes effort costs of $\frac{1}{4} c e^{4}$ and absolute risk aversion of one divided by five times salary. Because one period in our model corresponds to four calendar years, we annualize all figures in our table by dividing by four. We also display the sample medians for all values in the table.

We focus first on the smallest firm, listed in Column (1). This firm has a small number of employees, and makes modest option grants to middle-level managers. Assuming quadratic effort costs and a coefficient of absolute risk aversion of one, our model computes that the employee's additional productivity coming about as a result of the option grant is $\$ 10,200$, annually. The risk premium the employee attaches to his annual compensation on account of the option grant is $\$ 4,600$. The annual cost to the employee of exerting this additional effort is $\$ 2.60$.

The second calibration for this firm yields larger figures for effort and effort costs. To see the intuition for this, recall that our model solves for effort using the firm's first-order condition, which states that the marginal benefit and marginal cost associated with additional option grants must be equal. If employees are more risk averse, then the marginal cost to the firm of using option-based pay is higher. Hence, firms are willing to make the observed grants only if the responsiveness of effort to incentives is higher. For the small firm, the model indicates that the option grant causes a middle-level employee to produce an additional $\$ 50,600$ annually, at annual risk and effort costs of $\$ 11,500$ and $\$ 11$, respectively. The third calibration also yields higher effort figures than did

\footnotetext{
${ }^{22}$ The difference between non-executives and top 5 proxy-listed executives (which is the group typically studied) is very stark in the Execucomp dataset. Using 1996-2002, we used our methodology to estimate the value of grants to executives and non-executives at firms that meet our "SEC Plan1" criteria. The average (median) grants to the CEO 73 (89) are times as great as grants per non-executive. The average (median) grants to a non-CEO top 5 executive are 17 (22) times as great as grants per non-executive.
} 
the first. The cost-of-effort function here is flatter, meaning employees are more responsive to low-powered incentives. For the small firm, the model indicates that the option grant causes a middle-level employee to produce an additional $\$ 31,700$ annually, at annual risk and effort costs of $\$ 4,600$ and $\$ 4$, respectively.

Calibrations for the three other firms yield widely differing magnitudes. Our medium-large firm is notable in that it makes small option grants to middle managers. These grants impose small risk costs on employees, so the model infers that the value created and effort costs incurred by employees must be small as well. Our largest firm makes grants with a large Black-Scholes value, but because the firm has a very large number of shares outstanding, the employee's resulting share $(b)$ is very small. The model therefore infers that weak incentives must motivate employees to create a large amount of value. For this firm, the employee creates an additional $\$ 63,500$ annually, at risk and effort costs of $\$ 22,600$ and 2.3 cents.

We conclude from this exercise that the provision of incentives does not appear very plausible as an explanation for option-based pay. We base this conclusion on the following observation: In the case of the small firm and the first set of assumptions, options bring $\$ 10,200$ of additional benefits into the employee/firm relationship at a total cost (not including the risk costs) of less than three dollars. If this were the case, it seems clear that the parties' inability to contract on effort is generating a very substantial underprovision of effort. This difference, which strikes us as implausibly large, is implied by our agency model combined with the assumption that observed option grants reflect optimal incentives. This comparison is even more dramatic in the case of the large firm, where the additional benefits and costs of options are $\$ 63,500$ and about two cents, respectively.

The question we are left with is the following: Couldn’t the firm, at a cost of less than $\$ 22,600$, devise some other means of identifying whether an employee has taken actions that increase the value of the firm at trivial cost to the employee, and then reward the employee directly for these actions? Or, put another way, if additional effort would bring some amount on the order of $\$ 63,500$ into the employment relationship at a cost of a few cents, wouldn't the firm and employee figure out some way to split that surplus that did not require the employee to bear so much risk that the surplus was largely depleted? Even if "effort" cannot be objectively measured, it appears to us relatively straightforward for firms to use various forms of subjective performance evaluation to reward employees for value they create. Given our calculations here, we find it very difficult to believe that stock options could be the most efficient incentive mechanism available to firms. 
The most favorable case that can be made for options-as-incentives is this: options are sensible for incentive purposes under a very limited set of circumstances - namely, if employees take actions that have large value implications for the firm, the costs to the employee of taking these actions are very small, and it is extremely difficult for firms to observe whether employees are taking these actions.

\subsection{Sorting}

We now consider the sorting model discussed in Section 3.2, where potential employees vary in their beliefs about the firm's prospects. The intuition underlying our sorting calibration is the following: If sorting drives observed option grants, then the employee must prefer receiving the observed option package to an all-cash compensation package that costs the firm the same amount. Hence, we proceed by first computing the cost to the firm (salary plus Black-Scholes value of options) of observed compensation packages. We assume the firm would be willing to offer the employee an all-cash package costing the same amount, and then compute the set of values for employee risk tolerance and beliefs as to the firm's expected return under which the employee prefers the observed option package to the all-cash package.

We vary our analysis somewhat from the prior section while retaining most of the same basic assumptions. Let one period of our model correspond to four calendar years. Suppose again that options vest after four years, and that the employee exercises all options immediately upon vesting. Let $v_{1}$ be the terminal value of the firm, and suppose the employee believes it to be log-normally distributed with mean $v_{0}\left(1+r^{*}\right)^{4}$ and standard deviation $2 \sigma v_{0}$, where $\sigma$ is the annual standard deviation of returns. We determine the options' value when issued (which we use as the cost to the firm) using Black-Scholes assuming expiration in four years. Let the employee have constant relative risk aversion with initial wealth equal to his annual salary. ${ }^{23}$ We make assumptions regarding tax rates applied to three types of income: current salary, options profits, and additional cash salary the employee would receive if he got no stock options. Current salary is inframarginal in this analysis, so we apply $\tau_{s}=20 \%$ to capture an estimate of average tax rates in calculating utility. The other two types of earnings are marginal, so we apply $\tau_{b}=40 \%$.

Results are displayed graphically in Figures 1 through 4. To produce these graphs, we place the employee's coefficient of relative risk aversion on the $x$-axis and his expectation as to the

\footnotetext{
${ }^{23}$ While constant absolute risk aversion allowed us to simplify our analysis in the previous section, constant relative risk aversion is likely more realistic.
} 


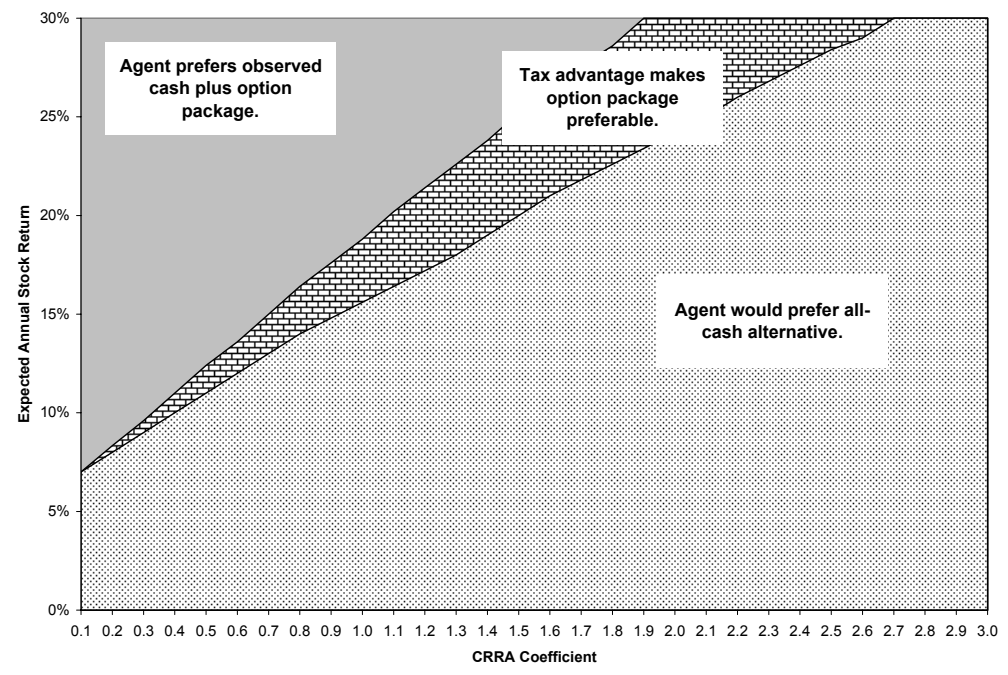

Figure 1: Small firm employee's preferences over compensation plans for different values of $r^{*}$ and $\rho$.

firm's annual stock return on the $y$-axis. For each point on this plane, we can compute whether an employee with these preferences and beliefs prefers the observed option package or an all-cash package that costs the firm the same amount. We also identify a region in which the tax advantages tips the employee's preference toward the option package. The four firms shown in the figures are the same four that we highlighted in Table 3.

We first consider an employee with coefficient of relative risk aversion 2.5 who expects his firm's share price to increase by $10 \%$ per year. At our small, medium-small, and large firms (Figures 1, 2, and 4), such an employee prefers an all-cash package costing the firm the same amount. The medium-large firm makes small option grants, and such an employee would prefer the observed salary plus option package because of the tax advantages. These conclusions do not change markedly when the employee is less risk averse. Lowering the employee's $\rho$ to 1 does not justify the use of options at the small, medium-small, or large firm, but the gap between the cost to the firm and the employee's valuation becomes smaller.

Next, we keep the employee's risk aversion relatively low, but assume he expects $25 \%$ annual stock appreciation (four-year appreciation of 144\%). The employees at all of the four firms in 


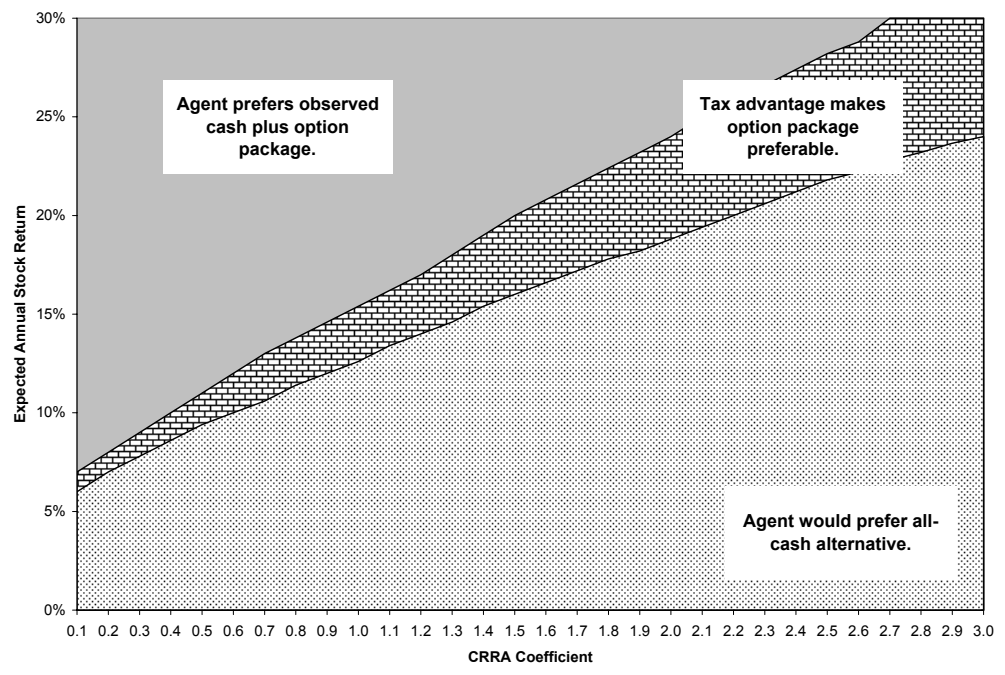

Figure 2: Med-Small firm employee's preferences over compensation plans for different values of $r^{*}$ and $\rho$.

Figures 1 through 4 now prefer the option package, as do the employees at 205 of the 216 firms in our sample. While $25 \%$ may seem like an excessively optimistic expectation, it is well below the average return at these firms in 1999. If employees naively believe there is momentum in share prices, then perhaps this figure is not far from accurate.

As discussed in Section 3.2, one reason why firms may attach options to the employment relationship (as opposed to simply letting employees trade on their own accounts) is if optimistic employees are more productive. If this is the case, then our assertion above that firms are indifferent between offering observed option packages and an all-cash package costing the firm the same amount is inaccurate. Firms would strictly prefer the option package if granting it also attracts a more productive employee. In this case, we can use our estimates from Table 3 to provide an estimate of what level of productivity differences would justify the options grants in the NCEO data. The expected return in these estimates is $10 \%$, suggesting the employee is only mildly optimistic. Depending on which firm we consider and what level of risk aversion we assume, optimistic employees would have to be anywhere from less than $\$ 100$ to over $\$ 50,000$ more productive annually. The required productivity differences at some extreme firms (especially the "large firm" in column 


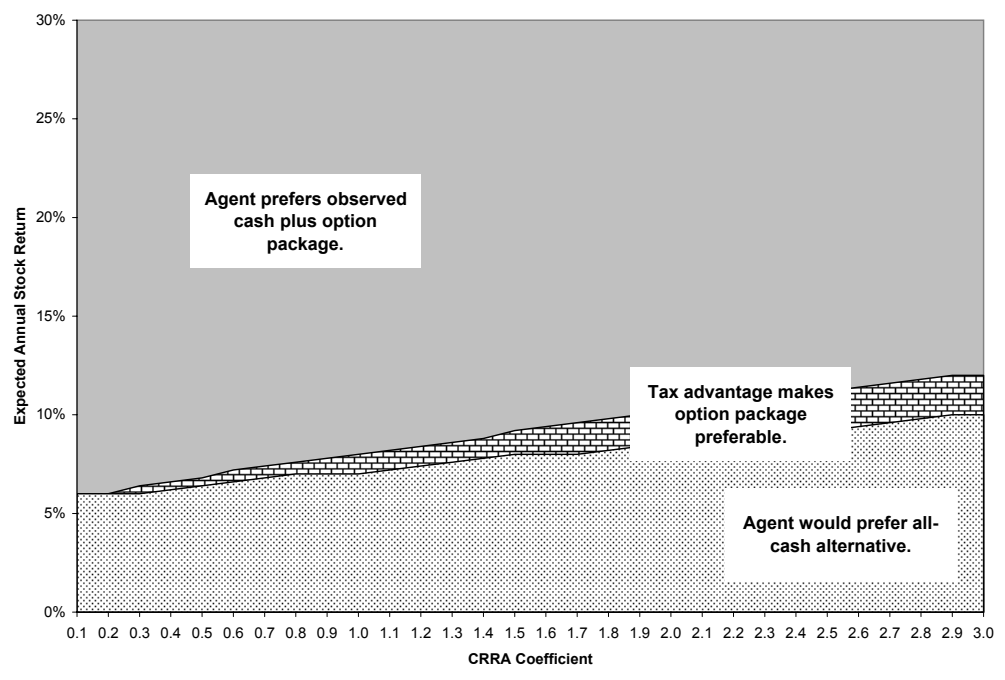

Figure 3: Med-Large firm employee's preferences over compensation plans for different values of $r^{*}$ and $\rho$.

(4)) seem implausible. However, the differences at the other firms and at the median firm appear consistent with the possibility that firms are willing to compensate optimistic workers for part of the risk premium of options compensation in order to attract more productive workers.

In general, we believe these results suggest that the sorting model could be at least a contributing factor in explaining why some firms offer stock options to lower level employees. If potential employees are somewhat risk tolerant and have optimistic views about the future of the firm, then employees will value cash-plus-options packages at more than their cost (net of productivity differences) to the firm. Full confirmation of this model will require an examination of across-firm variation in who uses stock options. Our calculations here indicate that, holding the employee's risk aversion constant, firms with lower stock volatility can more efficiently use stock options. Firms in the NCEO sample tend, however, to have very high volatilities. The fact that high-volatility firms use options is consistent with sorting only if these firms hire a selection of very risk tolerant employees, if the firm can locate extremely optimistic employees, or if optimistic employees are significantly more productive. 


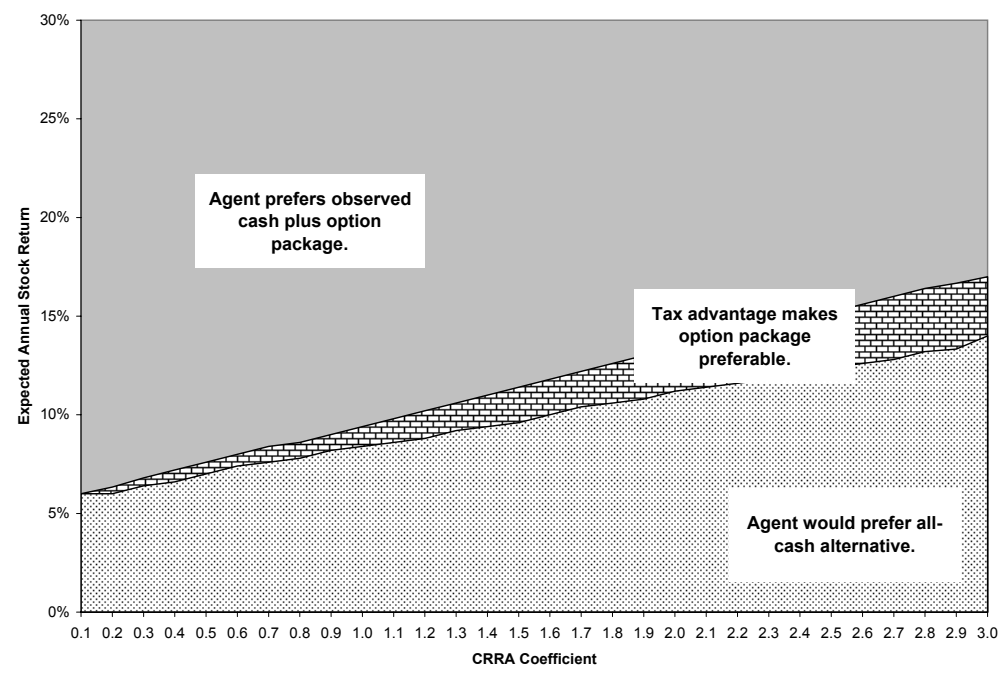

Figure 4: Large firm employee's preferences over compensation plans for different values of $r^{*}$ and $\rho$.

\subsection{Retention}

We now consider Oyer's (2003) explanation of option-based pay as a means for indexing the value of employees' deferred compensation to their outside options. The intuition underlying our retention calibration is the following: If options are intended to help firms index wages to market conditions, then short-run variation in the value of option packages must be of the same order of magnitude as short-run variation in spot wages. Given our detailed NCEO data on option grants, we can compute the short-run variation in the value of option packages, and use this to infer firms' expectations regarding wage variation.

We adjust the timing of our discussion somewhat to reflect the additional complexity of this model. Whereas previously we allowed one period in our model to represent four calendar years, we now assume that one period represents one calendar year. We assume a firm hires an employee at time $t=0$. Between $t=0$ and $t=1$, one of three states of the world is realized. With probability $q_{g}\left(q_{b}\right)$, industry conditions are revealed to be "good" ("bad"). Conditions are "unchanged" with probability $1-q_{g}-q_{b}$. The firm operates until time $t=4$, and then the model ends. 
Industry conditions affect both labor and financial markets. If industry conditions are good, then the employee could, at time $t=1$ obtain a job offer from another employer that pays wage $S_{g}$. If conditions are unchanged or bad, then the best offer the employee can get is $S_{u}$ or $S_{b}$, respectively, with $S_{g}>S_{u}>S_{b}$. Share prices are affected as follows:

$$
\begin{aligned}
\mathrm{E}\left[v_{1} \mid \text { Good state }\right] & =v_{g} \\
\mathrm{E}\left[v_{1} \mid \text { Unchanged state }\right] & =v_{u} \\
\mathrm{E}\left[v_{1} \mid \text { Bad state }\right] & =v_{b} .
\end{aligned}
$$

We let the unconditional expectation of $v_{1}$ equal $v_{u}$, which implies $q_{h}\left(v_{g}-v_{u}\right)=q_{b}\left(v_{u}-v_{b}\right)$. We also assume $\operatorname{Var}\left[v_{1} \mid s\right]=(3 / 5) \sigma^{2}$ for each state $s \in\{g, u, b\}$. In words, the variance of firm value conditional on industry prospects is equal to $60 \%$ of the unconditional variance, which means $40 \%$ of the total variance is determined by industry conditions. ${ }^{24}$ To compute the $v$ values, we first assume an expected rate of return, $r$, on the firm's shares. This determines $v_{u}$, as $\mathrm{E}\left[v_{1}\right]=v_{u}=(1+r) v_{0}$. We then solve for magnitudes $v_{g}$ and $v_{b}$ so that the unconditional variance of the firm's return is equal to $\sigma^{2}$.

When making hiring decisions, the firm must decide between offering spot wages and offering an option-based package. If the firm chooses spot wages, then it pays the employee $S_{u}$ in the first year. If industry conditions then turn good, the employee seeks an outside offer prior to $t=1$. The firm matches the offer and incurs transaction cost $k$ in doing so. ${ }^{25}$ If conditions turn bad, then the firm cannot adjust the employee's wage downward. After the first-period uncertainty is revealed, no further changes in industry conditions occur, and the employee works for three additional periods at the set wage. Hence, the expected cost to the firm of offering the spot wage job is

$$
S_{u}+3\left(q_{g} S_{g}+\left(1-q_{g}\right) S_{u}\right)+q_{g} k
$$

An option-based compensation package consists of a salary $S_{\text {opt }}$ and an option grant consisting of $n$ options with initial Black-Scholes value $\mathrm{BS}\left(v_{0}\right)$. We assume that the employee decides whether to

\footnotetext{
${ }^{24}$ We experimented with other allocations of risk between firms and industries, but found that it made surprisingly little difference. The choice of $60 \%$ idiosyncratic risk is based on several regressions we ran of individual firm returns on the NASDAQ composite index or the Dow Jones Internet Commerce and Internet Service Indexes. In practice, the amount of idiosyncratic risk is often reduced by firms' lowering the strike price of options.

${ }^{25}$ Alternatively, the parameter $k$ can be interpreted as a turnover cost — if the employee leaves, then the firm hires a new employee at the prevailing spot wage. Such a cost can arise from training or search.
} 
seek an outside offer after observing the realization of industry conditions, but before observing the realization of the idiosyncratic shock to his firm's value. ${ }^{26}$ The firm designs its option package with the aim of preventing the employee from seeking an outside offer in any state of the world. ${ }^{27}$ If the good state is realized, then the employee will choose not to seek an outside offer if, in expectation, he values his compensation from his current job at more than that at the next best job. If the employee does not seek another offer, then he remains with the firm and does not exercise any options until $t=4$. If the employee seeks an offer and takes it, then he exercises one-quarter of his options immediately. Thus, he will not seek an outside offer in state $s$ if

$$
\begin{aligned}
\int_{0}^{\infty} & \int_{0}^{\infty} U\left(W+5 S_{o p t}+n \max \left[\left(v_{4}-v_{0}\right), 0\right]\right) g\left(v_{4} \mid v_{1}\right) f\left(v_{1} \mid s\right) d v_{4} d v_{1} \geq \\
& \int_{0}^{\infty} U\left(2 S_{o p t}+3 S_{g}+\frac{n}{4} \max \left[v_{1}-v_{0}, 0\right]\right) f\left(v_{1} \mid s\right) d v_{1}
\end{aligned}
$$

where $f(\cdot \mid s)$ is the probability density function of the log-normal with mean $v_{s}$ and variance $\frac{3}{5} \sigma^{2} v$, and $g(\cdot \mid \cdot)$ is probability density function of the log-normal with mean $(1+r)^{3} v_{1}$ and variance $3 \sigma^{2} v .^{28}$ The firm prefers offering the option-based job to the spot wage job if

$$
S_{u}+3\left(q_{g} S_{g}+\left(1-q_{g}\right) S_{u}\right)+q_{g} k>4 S_{o p t}+\mathrm{BS}\left(v_{0}\right)
$$

These inequalities allow us to compute upper bounds on $S_{g}, S_{u}$, and $S_{b}$, and a lower bound on $k$. We also compute the "retention value" — that is, the Black-Scholes dollar value of options forfeited in the event the employee leaves - under the good and bad industry states.

The first case we consider, with $r^{*}=10 \%$ and $\rho=2.5$, suggest that contracting costs would have to be large at many firms in our sample in order for a retention argument to explain option grants made by firms in columns (1) and (3). In the event that spot wages increase, costs associated with re-contracting or replacing a manager for the firm in column (1) would have to be $\$ 45,000$ in order to justify the observed option grants. ${ }^{29}$ While human resource professionals say that replacement

\footnotetext{
${ }^{26}$ It may be more realistic to assume that the employee observes the value of the firm before determining whether to seek an outside offer. Under this assumption, the employee would seek an outside offer whenever the idiosyncratic shock to firm value is sufficiently negative. In designing its option package, the firm would need to choose under what realizations of idiosyncratic shocks it wants the option package to be large enough to retain the employee.

${ }^{27}$ This assumption - that turnover is never efficient — is a simplification. A more complex version of this model would trade off costs of adjusting wages with benefits of efficient matching.

${ }^{28}$ Note also that we assume the employee's outside wealth to be equal to $S_{\text {opt }}$.

${ }^{29}$ As noted above, we assume that, if spot wages decrease, the firm cannot lower the employee's cash compensation.
} 
Table 4: Calibration - Retention

\begin{tabular}{|c|c|c|c|c|c|}
\hline & $\begin{array}{l}\text { Small Firm } \\
\text { (1) }\end{array}$ & $\begin{array}{c}\text { Med-Small Firm } \\
(2)\end{array}$ & $\begin{array}{c}\text { Med-Large Firm } \\
(3)\end{array}$ & $\begin{array}{c}\text { Large Firm } \\
\text { (4) }\end{array}$ & $\begin{array}{c}\text { Median } \\
(5)\end{array}$ \\
\hline \multicolumn{6}{|c|}{ Annual Cash Compensation (from NCEO survey) } \\
\hline & $\$ 38$ & $\$ 100$ & $\$ 90$ & $\$ 90$ & $\$ 90$ \\
\hline \multicolumn{6}{|l|}{ Case One: $r^{*}=10 \%, \rho=2.5$} \\
\hline Initial Spot Wage $\left(S_{u}\right)$ & $\$ 41.3$ & $\$ 109.1$ & $\$ 92.3$ & $\$ 126.4$ & $\$ 92.6$ \\
\hline High Spot Wage $\left(S_{g}\right)$ & $\$ 42.7$ & $\$ 112.6$ & $\$ 93.5$ & $\$ 139.5$ & $\$ 93.7$ \\
\hline Low Spot Wage $\left(S_{b}\right)$ & $\$ 39.1$ & $\$ 104.1$ & $\$ 90.9$ & $\$ 113.3$ & $\$ 90.5$ \\
\hline Retention Value - High & $\$ 44.8$ & $\$ 71.6$ & $\$ 9.7$ & $\$ 190.8$ & $\$ 71.0$ \\
\hline Retention Value - Low & $\$ 6.7$ & $\$ 10.7$ & $\$ 1.5$ & $\$ 60.1$ & $\$ 15.6$ \\
\hline Transaction Cost $(k)$ & $\$ 45.3$ & $\$ 10.9$ & $\$ 0$ & $\$ 14.0$ & $\$ 33.3$ \\
\hline \multicolumn{6}{|l|}{ Case Two: $r^{*}=10 \%, \rho=1$} \\
\hline Initial Spot Wage $\left(S_{u}\right)$ & $\$ 44.6$ & $\$ 113.9$ & $\$ 92.6$ & $\$ 144.6$ & $\$ 99.4$ \\
\hline High Spot Wage $\left(S_{g}\right)$ & $\$ 48.3$ & $\$ 121.2$ & $\$ 94.1$ & $\$ 166.5$ & $\$ 104.6$ \\
\hline Low Spot Wage $\left(S_{b}\right)$ & $\$ 40.1$ & $\$ 105.6$ & $\$ 91.0$ & $\$ 123.6$ & $\$ 91.6$ \\
\hline Retention Value - High & $\$ 44.8$ & $\$ 71.6$ & $\$ 9.7$ & $\$ 190.8$ & $\$ 71.0$ \\
\hline Retention Value - Low & $\$ 6.7$ & $\$ 10.7$ & $\$ 1.5$ & $\$ 60.1$ & $\$ 15.6$ \\
\hline Transaction Cost $(k)$ & $\$ 0$ & $\$ 0$ & $\$ 0$ & $\$ 0$ & $\$ 0$ \\
\hline \multicolumn{6}{|l|}{ Case Three: $r^{*}=25 \%, \rho=1$} \\
\hline Initial Spot Wage $\left(S_{u}\right)$ & $\$ 51.5$ & $\$ 1267$ & $\$ 95.2$ & $\$ 241.7$ & $\$ 113.1$ \\
\hline High Spot Wage $\left(S_{g}\right)$ & $\$ 57.8$ & $\$ 138.7$ & $\$ 97.7$ & $\$ 284.7$ & $\$ 125.3$ \\
\hline Low Spot Wage $\left(S_{b}\right)$ & $\$ 44.4$ & $\$ 113.4$ & $\$ 92.5$ & $\$ 199.1$ & $\$ 100.6$ \\
\hline Retention Value - High & $\$ 50.4$ & $\$ 80.7$ & $\$ 11.0$ & $\$ 240.9$ & $\$ 81.8$ \\
\hline Retention Value - Low & $\$ 10.6$ & $\$ 16.9$ & $\$ 2.4$ & $\$ 97.1$ & $\$ 24.7$ \\
\hline Transaction Cost $(k)$ & $\$ 0$ & $\$ 0$ & $\$ 0$ & $\$ 0$ & $\$ 0$ \\
\hline
\end{tabular}

Risk-free rate is assumed to be $5 \%$. "Initial spot wage" is the implied market wage when middle manager receives the options grant and, if there is no common shock, one year later. "High spot wage" ("Low spot wage") is the implied maximum market wage for a middle manager one year after the options are granted and after a positive (negative) common shock. "Transaction cost" is the minimum expected costs the firm would incur over a four year period due to changes in the agent's compensation package and/or replacing the agent in order to justify the amount of stock options it grants to a middle manager. "Retention value" indicates expected Black-Scholes value (assuming he expects to exercise options four years after they are issued) forfeited if the employee takes the outside offer, given the value of the common shock. 
costs can be 25 to $50 \%$ of annual wages for some jobs, our estimates for the small firm and the median firm are at the high end of this range.

The second case, which assumes the worker is risk averse but less so $(\rho=1)$, lead to much more plausible estimates of the turnover or renegotiation costs necessary to justify the use of options. In all four firms in the table, for the median firm, and for a total of 134 of the 216 firms in our sample, our estimates suggest that firms benefit from using options even if they do not lower the cost of raising an employee's wage. That is, the firms in the table can justify the use of options at any positive turnover cost. ${ }^{30}$ However, for this conclusion to be credible, the model suggests that options can be used for retention purposes if spot wages fluctuate up or down anywhere from $\$ 2,000$ to $\$ 20,000$ over a short period. In this second set of estimates, the turnover or renegotiation costs are negligible and the amount of unvested option value would have a significant effect on employee retention. Therefore, the results suggest that the retention model can justify the use of stock options, if market wages for managers in this sample really vary by as much as Table 4 suggests.

The third case combines the sorting and retention models, by assuming the employee is optimistic regarding the firm's share price. Here, the retention argument can explain option grants even if spot wages vary $\$ 5,000$ to $\$ 40,000$ over a short horizon. The retention values grow as employees value their holdings more highly, and the critical values of turnover costs fall even further below zero. Note that the assumptions underlying the retention model reinforce the sorting model because, by assuming stock options only expose the employee to idiosyncratic risk on the margin, they lower the risk premium the employee would otherwise need to be paid. We therefore believe that the last two subsections and the bottom part of Table 4 provide evidence that some combination of sorting and retention could be contributing to decisions to issue stock options firm-wide.

As a result, our estimates of renegotiation costs only relate to the case of retaining the worker if his spot market wage increases.

${ }^{30}$ All else equal, options are relatively more attractive to employees in this section's analysis than in section 4.2 because employees are exposed to some risk regardless of what form their compensation takes. If the firm offers the spot wage job, the employee's compensation will fluctuate due to changes in spot wages. 


\section{Cross-Firm Variation in Option Plans}

In this section, we analyze cross-sectional variation in option plan adoption using our SEC data. ${ }^{31}$ We estimate a series of logit models using "SEC Plan," as defined in Section 2, as our dependent variable. To verify that our findings are not sensitive to the definition of our dependent variable, we define two additional indicators of option plans. SEC Plan2 equals one if the Black-Scholes value of options granted per non-executive employee in 1998 was at least $\$ 1,000$. Option grants are disproportionately made to new employees, so we construct a third indicator — SEC Plan3 - that adjusts for the possibility that option granting behavior depends on employment growth. We assume that all non-executive grants are given to new employees, and estimate the number of new employees to be the sum of the 1997 to 1998 increase in employment and $10 \%$ of the 1997 employment. We then set SEC Plan3 equal to one if the Black-Scholes value of options granted to each new employee is at least $\$ 2,500$. Because these additional variables are constructed using the market value of options granted, they are, by definition, related to firm and/or industry volatility. In regressions using these variables, we omit firm and industry volatility.

The explanatory variables include measures related to the comparative static implications of each model, as well as control variables. All of our analyses include controls for the log of the number of employees at the firm, the growth in number of employees from 1997 to 1998, and an indicator variable for "new economy" status, as defined above. Note the predicted effects of these controls on option usage do not vary in a way that would allow us to distinguish between the models. In unreported specifications, we also controlled for two-digit SIC code. This did not materially affect the results.

Agency theory predicts a negative relationship between risk and incentives, so the incentive model implies that option plans should be less common at high volatility firms. If higher volatility also reflects higher variance in people's beliefs about a firm, then the sorting model predicts that higher volatility firms (or firms in higher volatility industries) will be more likely to make broad option grants. The retention model predicts that non-executive option plans will be negatively related to idiosyncratic firm volatility, but positively related to the volatility of the set of firms that compete for a given group of employees. To test these implications, we use two volatility measures as explanatory variables. First, we include monthly firm stock volatility. In addition, we include

\footnotetext{
${ }^{31}$ We use the SEC data because it constitutes a random sample of public firms. However, we redid the analysis in this section for each year from 1996 through 2001 using all firms in Standard \& Poors Execucomp dataset. Virtually without exception, that analysis led to the same conclusions as the results we present below.
} 
"industry volatility," which we define as the standard deviation of the monthly average return for all CRSP firms in a given 4-digit SIC code industry. ${ }^{32}$

The retention model predicts that option plans will be more common at firms whose returns are more closely related to the returns of other firms that compete for the same set of workers. To test this implication, we generated a variable that we refer to as "industry volatility share." To construct this variable, we first run regressions of each CRSP firm's monthly returns on industry returns. ${ }^{33}$ We average the $R^{2}$ from these regressions and define this as the industry volatility share.

Finally, we include variables that proxy for variance in potential employees' beliefs about future returns and financing constraints. These include an indicator variable for positive cash flow in 1998, 1998 cash flow as a fraction of beginning-of-year capital, and 1998 investment as a fraction of beginning-of-year capital. We also include cash flow and investment as a fraction of beginningof-year market capitalization.

Results are in Table 5. First, note that option plans are more common at smaller firms and new economy firms. Firms with more employees are significantly less likely to have broad stock option plans. A firm with $10 \%$ more employees than another firm is one to one-and-a-half percentage points less likely to have a broad-based plan. ${ }^{34}$ New economy firms have a 33 percentage point higher probability of using a broad-based plan, holding the other factors in column (1) constant.

In contrast to the basic agency theory of an inverse risk/incentive relationship, we find that a firm with volatility that is 10 percentage points higher than another firm is more likely by 13 percentage points (that is, the probability increases by about one third) to have a broad plan. This provides further support for our conclusion in Section 4.1 that incentives are not an important cause of firms' decision to adopt broad option plans. The dramatically higher volatility of plan firms (and, as discussed below, their industries) contradicts every "informativeness" agency model.

Column (2) shows that the positive relationship between risk and option plans is largely driven by industry volatility rather than idiosyncratic firm volatility. Industry volatility is positively (and

\footnotetext{
${ }^{32}$ We exclude observations where there are not at least eight firms available to construct industry return.

${ }^{33}$ For inclusion here, we require firms to have twelve observations of monthly returns.

${ }^{34}$ Core and Guay (2001) report the opposite result, namely that the value of options grants per employee increases with firm size. Recall from our discussion in Section 2 that they define any option grant to an employee other than the five highest paid executives as a grant to a "non-executive." When we apply their definition, we also find that the likelihood of broad option plans increases with firm size. Thus, it seems their finding may be indicative that non-top five executives receive larger option grants at larger firms. Also note that this negative size/option plan relationship holds up in every year of the Execucomp dataset.
} 
significantly) related to option plans and, when controlling for industry volatility, firm volatility is not significantly related to option plans. This is consistent with the industry versus firm volatility prediction of the retention model. ${ }^{35}$ While the sorting model does not have as explicit a prediction about the relative importance of industry and firm volatility, this model is also consistent with the results in Table 5 if volatility is correlated with variance in employees' expectations about future returns.

We also add "industry volatility share" as an explanatory variable in column (2) and in the logits that use SEC Plan2 and SEC Plan3 as the dependent variable. While this variable does not show a significant relationship to option plan status in columns (2) and (6), it is positively and significantly related to SEC Plan2. This is consistent with the retention model because it suggests that firms are more likely to grant options if their returns are more closely related to other firms that could employ their workers.

In column (2), we find that positive cash flow is associated with a 22 percentage point lower probability (that is, it drops by approximately two thirds) of implementing a broad-based stock option plan. While this provides some potential support for the financing constraints hypothesis, columns (4) show that the other controls for financing constraints are not related to option grants. When we use SEC Plan2 or SEC Plan3 as the dependent variable, we find that firms that are making large investments relative to capital are more likely to have option plans. However, firms that are making larger investments relative to the value of their equity are, if anything, less likely to have option plans.

We believe the relationship between cash flow and option plans (and between investments and option plans) is consistent with the sorting model. Making investments (either in capital or in funding negative cash flow operations) does not necessarily indicate that a firm faces financing constraints. On the other hand, it does seem that investing firms are likely to be firms where future returns are variable and where the expectations about future returns vary across potential employees. If this is true, this suggests that firms are financing through employees when there are employees whose beliefs make them a relatively inexpensive source of capital.

We believe that the results in Table 5 are consistent with both the sorting and retention models, but they provide little reason to reverse our belief that incentive effects are not important in broadbased option plans. Though the negative association between employees and option plans would

\footnotetext{
${ }^{35}$ Carter and Lynch (2003) provide related cross-sectional support for the importance of retention. They show that option repricing is correlated with reductions in employee turnover.
} 
Table 5: SEC Option Plan Logits

\begin{tabular}{|c|c|c|c|c|c|c|}
\hline Dependent Variable & $\begin{array}{l}\text { SEC Plan } \\
\text { (1) }\end{array}$ & $\begin{array}{c}\text { SEC Plan } \\
(2)\end{array}$ & $\begin{array}{c}\text { SEC Plan } \\
(3)\end{array}$ & $\begin{array}{l}\text { SEC Plan } \\
(4)\end{array}$ & $\begin{array}{c}\text { SEC Plan2 } \\
(5)\end{array}$ & $\begin{array}{c}\text { SEC Plan3 } \\
(6)\end{array}$ \\
\hline Log Employees & $\begin{array}{l}-0.1472 \\
(0.0146)\end{array}$ & $\begin{array}{l}-0.1188 \\
(0.0172)\end{array}$ & $\begin{array}{l}-0.1209 \\
(0.0196)\end{array}$ & $\begin{array}{l}-0.1231 \\
(0.0181)\end{array}$ & $\begin{array}{l}-0.1770 \\
(0.0228)\end{array}$ & $\begin{array}{l}-0.1226 \\
(0.0190)\end{array}$ \\
\hline Employee Growth & $\begin{array}{c}0.0763 \\
(0.0441)\end{array}$ & $\begin{array}{c}0.0817 \\
(0.0485)\end{array}$ & $\begin{array}{c}0.0310 \\
(0.0383)\end{array}$ & $\begin{array}{c}0.0562 \\
(0.0478)\end{array}$ & $\begin{array}{c}0.0702 \\
(0.0545)\end{array}$ & $\begin{array}{l}-0.0449 \\
(0.0163)\end{array}$ \\
\hline Firm Volatility & $\begin{array}{c}1.3232 \\
(0.3279)\end{array}$ & $\begin{array}{c}0.6306 \\
(0.4071)\end{array}$ & $\begin{array}{c}0.3029 \\
(0.4212)\end{array}$ & $\begin{array}{c}0.5436 \\
(0.4183)\end{array}$ & & \\
\hline New Economy & $\begin{array}{c}0.3291 \\
(0.0676)\end{array}$ & $\begin{array}{c}0.2764 \\
(0.0738)\end{array}$ & $\begin{array}{c}0.2512 \\
(0.0757)\end{array}$ & $\begin{array}{c}0.2815 \\
(0.0749)\end{array}$ & $\begin{array}{c}0.3512 \\
(0.0775)\end{array}$ & $\begin{array}{c}0.1912 \\
(0.0666)\end{array}$ \\
\hline Positive Cash Flow & & $\begin{array}{l}-0.2215 \\
(0.0745)\end{array}$ & $\begin{array}{l}-0.2256 \\
(0.0749)\end{array}$ & $\begin{array}{l}-0.2225 \\
(0.0827)\end{array}$ & $\begin{array}{l}-0.2371 \\
(0.0779)\end{array}$ & $\begin{array}{c}0.0574 \\
(0.0710)\end{array}$ \\
\hline Industry Volatility & & $\begin{array}{c}2.3205 \\
(0.9440)\end{array}$ & $\begin{array}{c}1.9704 \\
(0.9881)\end{array}$ & $\begin{array}{c}2.1861 \\
(0.9497)\end{array}$ & & \\
\hline Industry Volatility Share & & $\begin{array}{l}-0.0831 \\
(0.1780)\end{array}$ & & & $\begin{array}{c}0.5065 \\
(0.2106)\end{array}$ & $\begin{array}{c}0.1888 \\
(0.1878)\end{array}$ \\
\hline Investment/Value & & & $\begin{array}{l}-0.1125 \\
(0.1919)\end{array}$ & & $\begin{array}{l}-0.6078 \\
(0.2741)\end{array}$ & $\begin{array}{l}-0.3424 \\
(0.2227)\end{array}$ \\
\hline Investment/Capital & & & $\begin{array}{c}0.1123 \\
(0.0602)\end{array}$ & & $\begin{array}{c}0.1832 \\
(0.0719)\end{array}$ & $\begin{array}{c}0.3473 \\
(0.0776)\end{array}$ \\
\hline Cash Flow/Value & & & & $\begin{array}{l}-0.0504 \\
(0.1475)\end{array}$ & & \\
\hline Cash Flow/Capital & & & & $\begin{array}{c}0.0016 \\
(0.0040)\end{array}$ & & \\
\hline Pseudo- $\mathrm{R}^{2}$ & 0.2818 & 0.2763 & 0.3057 & 0.2822 & 0.3962 & 0.2234 \\
\hline Sample Size & 765 & 573 & 479 & 549 & 479 & 439 \\
\hline
\end{tabular}

Dependent variables, described in the text, are various indicator variables for whether a firm has a broad-based stock option plan. Data are from a random sample of 1,000 firms that filed annual reports and proxy statements with the SEC in 1999. Sample size in each logit is based on the number of firms for which financial information, as well as industry stock return, was available. "New Economy" indicates primary SIC code is 3570-3579, 3661, 3674, 5045, 5961, or 7370-7379. Coefficients are marginal effects on the probability that the firm has a plan. Standard errors are in parentheses. 
lend some support to the moral hazard explanation of option use, our previous numerical analysis suggests that the marginal effects of the number of employees on incentives dissipate quickly as a firm grows and that these firms are generally above the level where we would expect such an association between size and incentives. More importantly, the strong positive relationship between risk and option plans contradicts a central prediction of the incentive model.

\section{Conclusion}

Using firm-level data on stock option grants and financial information, we have tried to reconcile the fact that some firms issue stock options to lower-level employees with economic theory. We focused on three classes of model - moral hazard, sorting on worker beliefs about the firm's prospects, and stock options as a relatively inexpensive way to adjust worker compensation to market conditions. Using details on the stock option plans for middle managers at a sample of over 200 firms, we showed that stock options appear to be an incredibly inefficient means of providing incentives to employees. By calibrating an agency model to data on actual grants of stock options to middle-level employees, we computed that risk premia associated with these grants are typically several orders of magnitude larger than the cost to employees of the resulting increases in effort. Our calibrations suggest that, if a typical firm in our sample were granting options to middle managers as a means of inducing them to increase effort, the firm would be paying each employee many thousands of dollars in risk premium in order to generate added effort that the employee values at less (often much less) than $\$ 100$. We conclude, based on these calculations, that stock options are an inefficient incentive mechanism for middle managers.

Though we cannot conclusively determine how important either model is, we interpret our analysis as consistent with both the sorting and retention models. We show that, if workers are sufficiently optimistic about their employers' prospects, stock options may be an efficient means of compensation. That is, despite demanding compensation for risk, optimistic employees may be willing to accept a large enough reduction in cash compensation to warrant using options as compensation. We also show that, if spot labor market rates are fairly variable and reducing worker wages is costly, then the correlation between the value of a worker's stock option holdings and his reservation utility may induce the firm to issue stock options.

We believe that neither accounting treatment of option grants, cash constraints, nor any of the three models we examined in this paper can single-handedly explain the use of broad-based stock 
option plans. The belief that the accounting treatment of options is solely responsible for their widespread use seems inconsistent with the cross-sectional variation in adoption of option plans and with the fact that so many firms with broad plans have been successful for long periods. As we discussed in Section 3.4, employees are too expensive a source of capital to justify the cash constraints explanation. We believe our estimates in Section 4.1 rule out the incentive model as a primary (much less exclusive) justification for broad option plans.

We think that the evidence in this paper suggests that sorting or retention may be first-order determinants of a typical firm's decision to adopt a broad-based stock option plan. But neither explanation can stand completely on its own. The sorting model begs a critical question of why firms and employees would agree to make employees' beliefs part of an inflexible employment contract, given that the tax advantages of using options are not very large relative to cash compensation. We also believe that, while we have demonstrated that stock options can be a useful tool for making compensation vary with an employee's market wage, it is a fairly crude tool for this purpose. If firms received no other benefits from option grants besides savings on the costs of adjusting compensation agreements, it seems likely they would try to find more specialized measures of employee's market value that did not expose the employee to so much idiosyncratic firm risk. It is therefore our belief that the firms that adopt broad option plans are those where the returns to cost effectively attracting and retaining employees is particularly high. But those firms may well choose option plans (as opposed to stock grants, profit sharing, or other pay mechanisms) as a means towards these ends for secondary reasons such as accounting treatment or a need to find a simple metric upon which to base pay. 


\section{References}

Aboody, D.: 1996, Market valuation of employee stock options, Journal of Accounting and Economics 22, 357-391.

Aboody, D., Barth, M. E. and Kasznik, R.: 2001, SFAS 123 stock-based compensation expense and equity market values, Research Paper 1694, Graduate School of Business, Stanford University.

Aggarwal, R. and Samwick, A. A.: 1999, The other side of the tradeoff: The impact of risk on executive compensation, Journal of Political Economy 108, 65-105.

Barron, J. M. and Waddell, G. R.: 2003a, Executive rank, pay and project selection, Journal of Financial Economics 67, 305-349.

Barron, J. M. and Waddell, G. R.: 2003b, Hard work versus good intentions: Stock options as compensation. Purdue University and University of Oregon.

Bell, T., Landsman, W., Miller, B. and Yeh, S.: 2002, The valuation implications of employee stock-option accounting for profitable computer software firms, Accounting Review 77, 971-996.

Bergman, N. and Jenter, D.: 2003, A note on employee sentiment and stock option compensation. Sloan School, Massachusetts Institute of Technology.

Bull, C.: 1987, The existence of self-enforcing implicit contracts, Quarterly Journal of Economics 102, 147160.

Bushman, R. M., Indjejikian, R. J. and Smith, A.: 1995, Aggregate performance measures in business unit manager compensation: The role of intrafirm interdependencies, Journal of Accounting Research 33, 101-128.

Carter, M. E. and Lynch, L. J.: 2003, The effect of stock option repricing on employee turnover. The Wharton School, University of Pennsylvania and Darden Graduate School of Business, University of Virginia.

Core, J. E. and Guay, W. R.: 2001, Stock option plans for non-executive employees, Journal of Financial Economics 60, 253-267.

Friend, I. and Blume, M. R.: 1975, The demand for risky assets, American Economic Review 65, 900-922.

Garvey, G. T. and Milbourn, T. T.: 2002, Do stock prices incorporate the potential dilution of employee stock options? Claremont Graduate School and Washington University.

Gompers, P. A., Ishii, J. L. and Metrick, A.: 2003, Corporate governance and equity prices, Quarterly Journal of Economics 118, 107-155.

Hall, B. J. and Murphy, K. J.: 2002, Stock options for undiversified executives, Journal of Accounting and Economics 33. 3-42. 
Hall, B. J. and Murphy, K. J.: 2003, The trouble with stock options, Journal of Economic Perspectives 17. Forthcoming.

Holmstrom, B. and Milgrom, P. R.: 1987, Aggregation and linearity in the provision of intertemporal incentives, Econometrica 55, 308-328.

Holmstrom, B. and Milgrom, P. R.: 1991, Multi-task principal-agent analyses: Incentive contracts, asset ownership and job design, Journal of Law, Economics and Organization 7, 524-552.

Huddart, S. and Lang, M.: 1996, Employee stock option exercises: An empirical analysis, Journal of Accounting and Economics 21, 5-43.

Huddart, S. and Lang, M.: 2003, Information distribution within firms: Evidence from stock option exercises, Journal of Accounting and Economics 34, 3-31.

Huson, M. R., Scott, T. W. and Wier, H. A.: 2001, Earnings dilution and the explanatory power of earnings for returns, Accounting Review 76, 589-612.

Ittner, C. D., Lambert, R. A. and Larcker, D. F.: 2003, The structure and performance of equity grants to employees of new economy firms, Journal of Accounting and Economics 34, 89-127.

Jin, L.: 2002, CEO compensation, diversification, and incentives, Journal of Financial Economics 66, 29-63.

Keating, A. S.: 1997, Determinants of divisional performance evaluation practices, Journal of Accounting and Economics 24, 243-273.

Kedia, S. and Mozumdar, A.: 2002, Performance impact of employee stock options. Working Paper, Harvard Business School.

Kruse, D. L.: 1993, Profit Sharing: Does it Make a Difference?, W.E. Upjohn Institute for Employment Research, Kalamazoo, MI.

Lazear, E. P.: 2001, Output-based pay: Incentives, retention or sorting? Stanford University.

McDonald, R. L.: 2003, The tax (dis)advantage of a firm issuing options on its own stock, Journal of Public Economics . Forthcoming.

Mehran, H. and Tracy, J.: 2001, The effect of employee stock options on the evolution of compensation in the 1990s, Federal Reserve Bank of New York Economic Policy Review 7, 17-34.

Murphy, K. J.: 2000, Executive compensation, in O. Ashenfelter and D. Card (eds), Handbook of Labor Economics, Vol. 3, North-Holland, Amsterdam.

Oyer, P.: 2003, Why do firms use incentives that have no incentive effects?, Journal of Finance . Forthcoming.

Oyer, P. and Schaefer, S.: 2003, A comparison of options, restricted stock, and cash for employee compensation. Stanford Graduate School of Business. 
Prendergast, C.: 2002, The tenuous trade-off between risk and incentives, Journal of Political Economy 110, 1071-1102.

Sesil, J. C., Kroumova, M. K., Blasi, J. R. and Kruse, D. L.: 2002, Broad-based employee stock options in U.S. 'new economy' firms, British Journal of Industrial Relations 40, 273-294.

Stein, J. C.: 2001, Agency, information, and corporate investment, in G. Constantinides, M. Harris and R. Stulz (eds), Handbook of the Economics of Finance, Vol. 1, North-Holland.

Weitzman, M. L. and Kruse, D. L.: 1990, Profit sharing and productivity, in A. S. Blinder (ed.), Paying for Productivity, The Brookings Institution. 